\title{
Measured and predicted energy use and indoor climate before and after a major renovation of an apartment building in Sweden
}

Lina La Fleur, Bahram Moshfegh and Patrik Rohdin

The self-archived postprint version of this journal article is available at Linköping University Institutional Repository (DiVA):

http:/ / urn.kb.se/ resolve?urn=urn:nbn:se:liu:diva- 138876

N.B.: When citing this work, cite the original publication.

La Fleur, L., Moshfegh, B., Rohdin, P., (2017), Measured and predicted energy use and indoor climate before and after a major renovation of an apartment building in Sweden, Energy and Buildings, 146, 98-110. https:// doi.org/ 10.1016/j.enbuild.2017.04.042

Original publication available at:

https:/ / doi.org/ 10.1016/j.enbuild.2017.04.042

Copyright: ELSEVIER SCIENCE SA

https://www.elsevier.com/

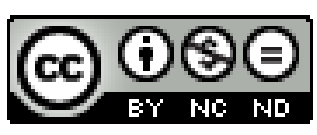




\title{
Measured and predicted energy use and indoor climate before and after a major renovation of an apartment building in Sweden
}

\author{
La Fleur, Lina ${ }^{a}$ (lina.la.fleur@liu.se), corresponding author \\ Moshfegh, Bahrama, \\ Rohdin, Patrik ${ }^{\mathrm{a}}$ \\ ${ }^{a}$ Division of Energy Systems, Department of Management and Engineering, Linköping University, Linköping, \\ Sweden \\ ${ }^{\mathrm{b}}$ Division of Building, Energy and Environment Technology, Department of Technology and Environment, \\ University of Gävle, Gävle, Sweden
}

\section{Highlights}

- Energy use and indoor climate of a building are studied before and after a renovation

- The study numerically predicts, validates and evaluates energy use and indoor climate

- Energy demand is reduced by $44 \%$ after renovation and indoor climate is improved

- Assumed user behavior has significant impact on estimated energy-saving potential

- System boundary affects climate and resource impact from selected renovation measures

\begin{abstract}
This article presents a case study of a renovated Swedish apartment building with a common design built in 1961. The aim is to present numerical predictions, validation and evaluation of energy use and indoor climate for the building before and after renovation. Comprehensive field measurements were carried out before and after the renovation to be used as input data in the building energy simulation tool IDA ICE and for validation of model results. Indoor temperature is predicted with maximum standard deviation of $0.4^{\circ} \mathrm{C}$ during winter. Annual heat demand is in good agreement with measurements. The building had an annual climate normalized district heat demand of 99.0 MWh before renovation and 55.4 MWh after, resulting in a $44 \%$ reduction. A slight under-prediction of the saving potential is noted, since the indoor air temperature has increased after the renovation. The results also show that assumptions of user behavior have significant impact on the energy-saving potential, and that choice of renovation measures, such as level of insulation, and efficiency of the ventilation heat recovery system need careful consideration. Choice of system boundaries also has a major effect on climate and resource impact from selected renovation measures.
\end{abstract}

\section{Introduction}

Residential buildings represent about $23 \%$ of the total energy use in the European Union [1]. Improving energy efficiency in the older part of our housing stock has become central to reducing energy use in the building sector overall. Space heating remains the largest share of energy use in buildings, representing between $60-80 \%$ of total energy use in regions with cold climate [2]. Renovation of buildings can significantly reduce space heating demand, and studies have shown great potential for energy saving by improving the thermal quality of the climate 
envelope [3-5], and installing ventilation heat recovery systems [4,5]. Changes in buildings not only impact building energy use, but also have a significant effect on surrounding energy systems, resource use and climate impact [6]. The Energy Performance of Buildings Directive (EBPD) recognizes that when buildings are in need of major renovation, opportunities for reducing energy use emerge [7]. The EBPD defines major renovations as renovations where the costs for renovating the climate envelope and technical building installations comprise more than $25 \%$ of the value of the building, or when more than $25 \%$ of the climate envelope is changed.

Around 35\% of Swedish apartments are located in buildings constructed between 1961-75 [8], a record-breaking period for residential construction in Sweden. In 2003, the Swedish National Board of Housing, Building and Planning performed an extensive investigation of the Swedish housing stock and concluded that the rate of renovation needed to increase threefold within the next 15 to 20 years, mainly in multifamily buildings from this period [8]. It is estimated that around $75 \%$ of these buildings are in need of some sort of renovation [9]. The importance of improving energy efficiency when renovations are performed was recognized in the Swedish Budget Bill for 2017, where 105 million EUR is budgeted for renovation and improvement of energy efficiency in multifamily buildings [10].

Several major renovation projects in similar climatic conditions as the case presented in this study have been reported in the most recent years. In order to compare the results from this study nine other projects are presented, see Table 1. All renovations included thermal improvements of the building envelope and installation of a heat recovery system. Control systems, such as demand controlled ventilation, was implemented in three of the nine cases. Substantial thermal improvements were made in project Brogården and Katjas gata and significant energy savings were achieved. Significant energy use reductions were also seen in the renovations where solar installations have been implemented. 


\begin{tabular}{|c|c|c|c|c|c|c|c|c|c|c|}
\hline Location & Project name & 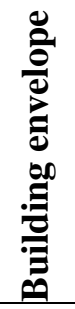 & 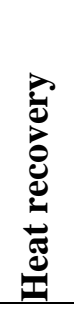 & 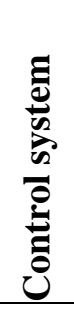 & 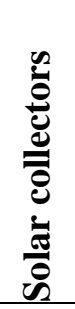 & 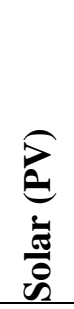 & $\begin{array}{r}\text { Energ } \\
(\mathrm{kWh} / \mathrm{m} \\
\text { Before }\end{array}$ & $\begin{array}{l}\text { y use } \\
\cdot \text { year) } \\
\text { After }\end{array}$ & Reduction & Ref \\
\hline Allingsås, Sweden & Brogården & $\mathrm{X}$ & $\mathrm{X}$ & & & & 177 & 58 & $67 \%$ & {$[11]$} \\
\hline Gothenburg, Sweden & Gårdsten & $\mathrm{X}$ & $\mathrm{X}$ & $\mathrm{X}$ & $\mathrm{X}$ & & 263 & 145 & $45 \%$ & {$[11]$} \\
\hline Gothenburg, Sweden & Katjas gata & $\mathrm{X}$ & $\mathrm{X}$ & & & & 178 & 52 & $71 \%$ & {$[11]$} \\
\hline Linköping, Sweden & Magistratshagen & $\mathrm{X}$ & $\mathrm{X}$ & & & & 131 & 80 & $39 \%$ & {$[12]$} \\
\hline Halmstad, Sweden & Maratonvägen & $\mathrm{X}$ & $\mathrm{X}$ & & & & 145 & 92 & $37 \%$ & {$[13,14]$} \\
\hline Hvalso, Denmark & Traneparken & $\mathrm{X}$ & $\mathrm{X}$ & $\mathrm{X}$ & & & 139 & 96 & $31 \%$ & {$[15]$} \\
\hline Roskilde, Denmark & Sems Have & $\mathrm{X}$ & $\mathrm{X}$ & & & $\mathrm{X}$ & 156 & 51 & $67 \%$ & {$[13,14]$} \\
\hline Kapfenberg, Austria & Kapfenberg & $\mathrm{X}$ & $\mathrm{X}$ & $\mathrm{X}$ & & $X$ & 146 & 46 & $68 \%$ & {$[13,14]$} \\
\hline Vilnius, Estonia & Project I-464 & $\mathrm{X}$ & $\mathrm{X}$ & & & & 212 & 132 & $38 \%$ & {$[16]$} \\
\hline
\end{tabular}

* including domestic hot water

Building energy simulation (BES) is a powerful tool for predicting the effects from renovation or other energy measures, and is widely used in the planning phase of renovation or new construction. However, previous research indicates that there is a lack of post-occupancy evaluation of building energy performance [17]. Several authors have also indicated a gap between predicted and measured energy use in both newly constructed and renovated buildings [17-21]. It is widely agreed that user behavior and occupancy is one reason for differences in expected, modelled or calculated and actual performance of buildings [21-25]. Dar et al. shows that different user behavior can cause a deviation of up to $12 \%$ from predicted energy use [21]. De Wilde argues that uncertainties in the design stage is another reason for a performance gap [17]. This study both evaluates the technical aspects of a major renovation and takes into consideration the realistic conditions under which the building is used by an extensive empirical validation of a BES model.

This article presents a case study of a major renovation of an apartment building in Sweden. The aim of this study is to present numerical predictions, validation and evaluation of energy use and indoor climate for the studied building before and after renovation, and to analyze how different choices of renovation strategies, user behavior and the efficiency of the ventilation heat recovery system impact energy performance. Comprehensive field measurements have been performed in the building and reference apartments during occupancy before and after the renovation and are used as input data in a BES model and for validation of modelled results. Resource and climate impacts are analyzed based on energy use-related $\mathrm{CO}_{2}$ emissions and primary energy use. 


\section{Case description and methodological approach}

The building was modelled in IDA ICE version 4.6.2 using field measurements and other available information about the building, such as blueprints. IDA ICE is a general simulation framework released in 1998 [26] that offers detailed dynamic simulation for building energy use, heating loads and indoor climate. Energy needed for domestic hot water is excluded from the simulations, and any reference to energy performance or heat demand therefore refers to thermal energy needed for space heating, unless otherwise stated.

\subsection{Case description}

The studied building is an apartment building with district heating located in southeastern Sweden, owned by a municipal company. It was constructed in 1961 and underwent major renovation in 2014. The building has five stories that hold twelve apartments. The original construction was light weight concrete (LWC) and the building was ventilated with an exhaust air system. The windows were non-gas filled, clear glass 3-pane and 2-pane windows. The building was in need of renovation primarily since interior surfaces were worn, and kitchen and bathrooms were in need of an upgrade. Previous studies also indicate that obsolescence in installations is the primary reason for renovation, rather than failure in durability or environmental reasons [27]. There was also a desire to reduce energy use in the building and hence thermal properties of the building were improved, see Table 2. $U$-values are calculated from thermal conductivity of materials and their thickness, in accordance with ISO standard 6946 [28]. Information in original blueprints was used. The predefined values for thermal bridges in IDA ICE were used and all were set to "typical." IDA ICE then assigns loss factors in $\mathrm{W} / \mathrm{K} /$ meter joint or perimeter. Loss factors vary between $0.03-0.05 \mathrm{~W} / \mathrm{K} \cdot \mathrm{m}$ for connections between internal walls and slabs and external elements (roof, external walls and external slab), as well as around windows and doors. External walls in connection to external elements have loss factors varying between $0.08-0.14 \mathrm{~W} / \mathrm{K} \cdot \mathrm{m}$. Exact values can be found in IDA ICE version 4.6.2. 
Table 2. Construction, thermal properties and window $g$-value before and after renovation.

\begin{tabular}{|c|c|c|c|c|c|}
\hline Segment & Area & $\begin{array}{l}\text { Original } \\
\text { Construction }\end{array}$ & $\begin{array}{l}U \text {-value* } \\
\left(\mathbf{W} / \mathbf{m}^{2} \cdot \mathbf{K}\right)\end{array}$ & $\begin{array}{l}\text { Renovated } \\
\text { construction }\end{array}$ & $\begin{array}{l}U \text {-value* } \\
\left(\mathbf{W} / \mathbf{m}^{2} \cdot \mathbf{K}\right)\end{array}$ \\
\hline External walls & $569.9 \mathrm{~m}^{2}$ & $\begin{array}{l}0.01 \mathrm{~m} \text { plaster board, } \\
0.25 \mathrm{~m} \text { LWC, } \\
\text { Cladding }\end{array}$ & 0.43 & $\begin{array}{l}0.01 \mathrm{~m} \text { plaster board } \\
0.25 \mathrm{~m} \text { LWC, } \\
0.1 \mathrm{~m} \text { mineral wool, } \\
\text { Cladding }\end{array}$ & 0.2 \\
\hline $\begin{array}{l}\text { Windows (incl. } \\
\text { balcony doors) }\end{array}$ & $112.1 \mathrm{~m}^{2}$ & 3-pane & $2.0^{* *}$ & $\begin{array}{l}\text { 3-pane } \\
\text { emissivity) }\end{array}$ & $1.1^{* *}$ \\
\hline $\begin{array}{l}\text { Bathroom } \\
\text { windows }\end{array}$ & $5.9 \mathrm{~m}^{2}$ & 2-pane & $2.9^{* *}$ & $\begin{array}{l}\text { 3-pane } \\
\text { emissivity) }\end{array}$ & $1.1^{* *}$ \\
\hline Doors*** & $3.8 \mathrm{~m}^{2}$ & Metal with glazing & 2.5 & Oak door & 0.8 \\
\hline Floor & $216.5 \mathrm{~m}^{2}$ & $\begin{array}{l}0.2 \mathrm{~m} \text { concrete, } \\
0.1 \mathrm{~m}^{\text {insulation }} \\
\text { Ground }^{* * * *}\end{array}$ & 0.2 & Unchanged & 0.2 \\
\hline $\begin{array}{l}\text { Ceiling towards } \\
\text { roof }\end{array}$ & $23.1 \mathrm{~m}^{2}$ & $\begin{array}{l}0.15 \mathrm{~m} \text { concrete, } \\
0.04 \mathrm{~m} \text { cork } \\
\text { Roofing tile }\end{array}$ & 0.91 & $\begin{array}{l}0.15 \mathrm{~m} \text { concrete, } \\
0.04 \mathrm{~m} \text { mineral wool } \\
\text { Roofing tile }\end{array}$ & 0.71 \\
\hline $\begin{array}{l}\text { Ceiling towards } \\
\text { attic }\end{array}$ & $194.5 \mathrm{~m}^{2}$ & $\begin{array}{l}0.05 \text { m concrete, } \\
0.12 \mathrm{~m} \text { mineral wool, } \\
0.2 \mathrm{~m} \text { concrete }\end{array}$ & 0.27 & $\begin{array}{l}0.05 \text { m concrete, } \\
0.3 \mathrm{~m} \text { mineral wool, } \\
0.2 \mathrm{~m} \text { concrete }\end{array}$ & 0.12 \\
\hline Total & $1125.8 \mathrm{~m}^{2}$ & & 0.54 & & 0.29 \\
\hline \multicolumn{3}{|c|}{ Other information } & Original & & New \\
\hline \multicolumn{3}{|c|}{ Windows solar gain factor ( $g$-value) } & 0.68 & & 0.43 \\
\hline \multicolumn{3}{|l|}{ Heated floor area } & $1072.5 \mathrm{~m}^{2}$ & & $1072.5 \mathrm{~m}^{2}$ \\
\hline \multicolumn{3}{|c|}{$\begin{array}{l}\text { Assumed losses from thermal bridges } \\
\text { (based on "typical" loss factors in IDA ICE) }\end{array}$} & $43.2 \mathrm{~W} / \mathrm{K}$ & & $42.9 \mathrm{~W} / \mathrm{K}$ \\
\hline \multicolumn{6}{|c|}{$\begin{array}{l}* U \text {-values calculated in accordance with ISO } 6946-\text { Building components and building elements-Thermal resistance and thermal transmittance }[28] \text {. } \\
\text { Values for thermal conductivity: light weight concrete }=0.12 \mathrm{~W} / \mathrm{m} \cdot \mathrm{K}, \text { mineral wool }=0.036 \mathrm{~W} / \mathrm{m} \cdot \mathrm{K} \text {, cladding }=0.8 \mathrm{~W} / \mathrm{m} \cdot \mathrm{K}, \text { concrete }=1.7 \mathrm{~W} / \mathrm{m} \cdot \mathrm{K} \text {, } \\
\text { cork }=.0 .5 \mathrm{~W} / \mathrm{m} \cdot \mathrm{K} \\
* * \text { Standard } U \text {-values for windows (IDA ICE version 4.6.2) } \\
* * * \text { Information from manufacturer } \\
\text { **** Ground properties and floor } U \text {-value calculated in accordance with ISO } 13370-\text { Thermal performance of buildings -- Heat transfer via the ground } \\
- \text { - Calculation methods [29] }\end{array}$} \\
\hline
\end{tabular}

Insulation was added to the entire façade, new well-insulated windows were installed and the attic was insulated. The mean $U$-value was calculated as the sum of each segment's transmission losses divided by the total external area. The mean $U$-value was reduced from 0.54 to $0.29 \mathrm{~W} / \mathrm{m}^{2} \cdot \mathrm{K}$. The exhaust ventilation system was replaced with a mechanical supply and exhaust ventilation system with heat recovery. Figure 1 shows a comparison of the heat balance of the unrenovated and renovated building modelled with the validated building model and normalized climate data. 

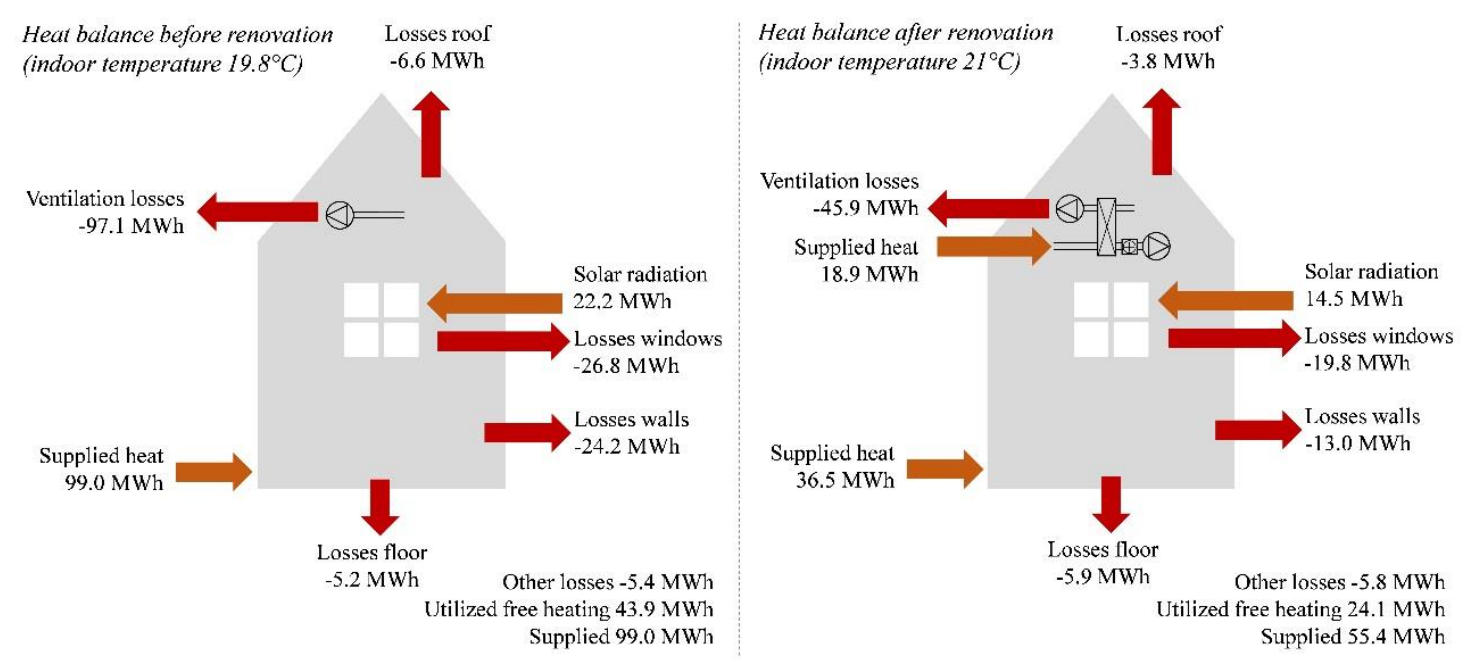

Figure 1. Heat balance of the unrenovated and renovated building with normalized climate data (modelled with validated model in IDA ICE 4.6.2).

Both transmission losses and ventilation losses have been significantly reduced. There is a slight increase in transmission losses through the floor and other losses (such as infiltration) in the renovated building, since the indoor temperature is higher after the renovation. Although the new windows reduce the heat losses, they also give smaller solar heat gains, due to the lower solar gain factor; 16 MWh compared to 24.4 MWh. The internal heat gains from appliances are the same before and after renovation, but a larger share is useful heat gains, free heating, before the building was renovated.

\subsection{Field measurements}

Field measurements were performed in two occupied reference apartments, one renovated and one unrenovated. The reference apartments were similar in size and located in the same part of the building, see Figure 2. The tenant in the unrenovated apartment did not move back in after the renovation was performed and the new resident was uninterested in participating in the study. Hence another reference apartment was used after the renovation. 


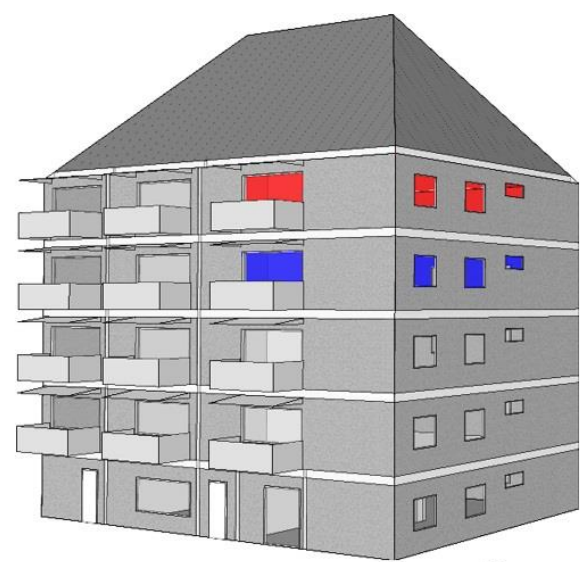

Unrenovated reference apartment

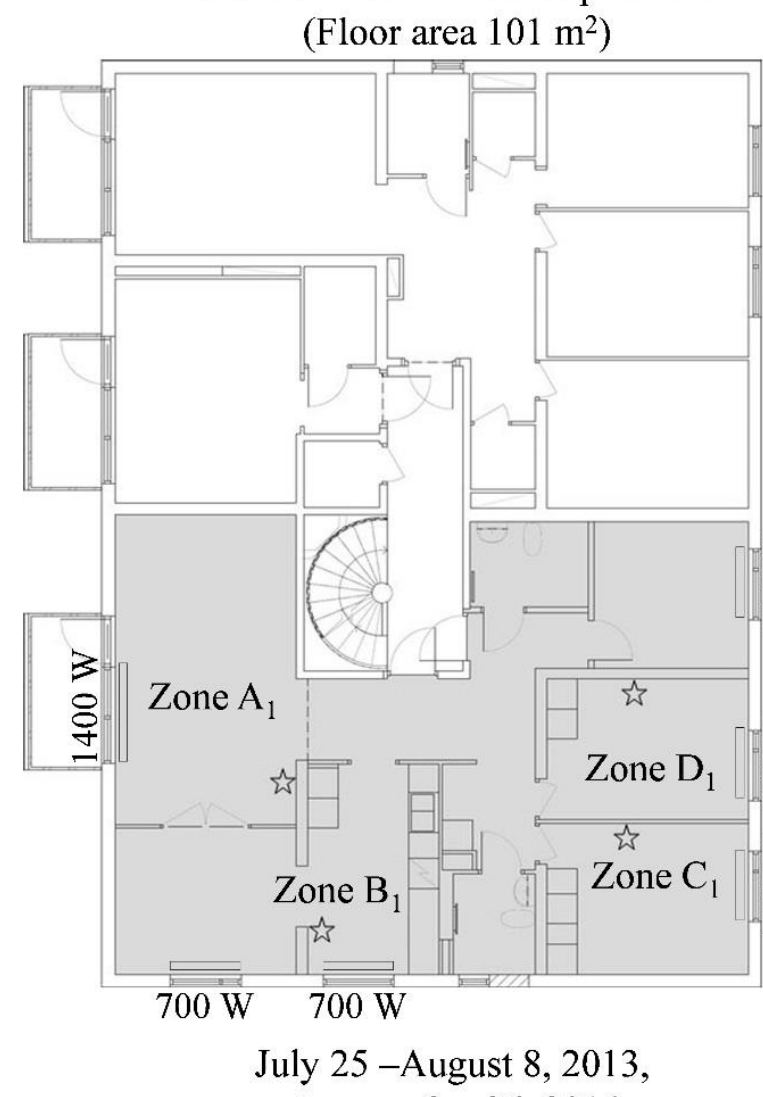

January $2-26,2014$
Renovated reference apartment

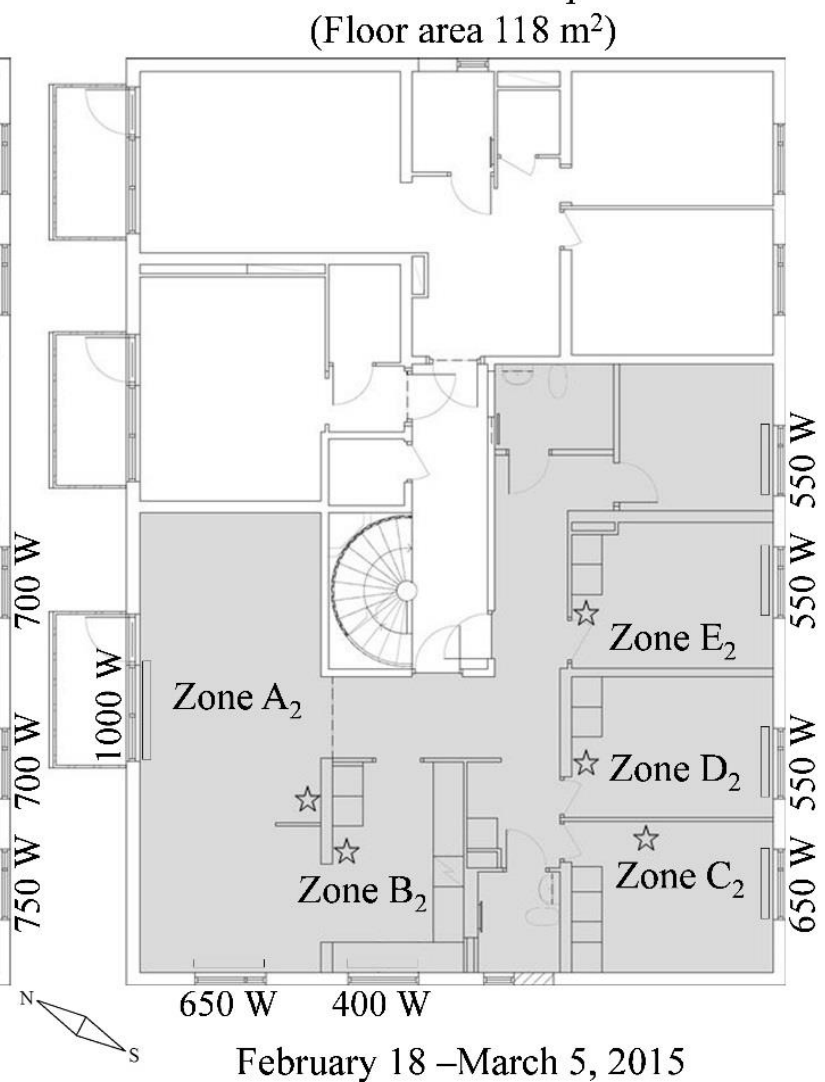

February 18 -March 5, 2015

Figure 2. Localization of the unrenovated (red) and renovated (blue) reference apartments above, apartment layouts, position of air temperature measurements (marked with stars), maximum thermal power from room heating units and time periods for measurements below.

The data collection in the renovated building occurred during a warmer winter than normal (around $1.5^{\circ} \mathrm{C}$ higher than the mean temperature during the last 20 years). Air temperature was measured in the living room (zone A), kitchen (zone B) and main bedrooms (zone C-E) and concentration of carbon dioxide was measured in master bedrooms (zone C). Electricity use was logged at five-minute intervals with an EliQ optical eye in the unrenovated apartment and collected from the electricity grid provider of the renovated reference apartment. Outdoor air temperature, relative humidity, wind direction and wind velocity were measured 
during the same time. A summary of equipment used and their accuracy can be seen in Table 3.

Table 3. Measurement equipment, use and equipment accuracy.

\begin{tabular}{|c|c|c|c|}
\hline Equipment & Measures & Equipment accuracy & Reference \\
\hline $\begin{array}{l}\text { Retrotech blower door } \\
1000 \text { and } 3100^{*} \text {-series, } \\
\text { with DM- } 2 \text { digital gauge }\end{array}$ & Climate envelope airtightness & $\begin{array}{l} \pm 3 \% \text { resp. } \pm 5 \% \text { flow } \\
\text { rate accuracy, } \\
\pm 1 \% \text { pressure reading } \\
\text { accuracy (or } \pm 0.15 \mathrm{~Pa} \text { ) }\end{array}$ & {$[30-32]$} \\
\hline Tiny Tag Plus 2 & Temperature \& relative humidity & $\begin{array}{l} \pm 0.35^{\circ} \mathrm{C}, \pm 3 \% \text { relative } \\
\text { humidity }\end{array}$ & {$[33]$} \\
\hline Tiny Tag $\mathrm{CO}_{2}$ logger & Cons & $\pm 3 \%$ & [34] \\
\hline EliQ optical eye & Hous & N/A & [35] \\
\hline $\begin{array}{l}\text { Irox PRO-X2 Weather } \\
\text { Station }\end{array}$ & $\begin{array}{l}\text { Wind velocity \& wind } \\
\text { Direction }\end{array}$ & $\begin{array}{l} \pm 5 \% \text { wind velocity, } \\
\pm 11.25^{\circ} \text { wind direction }\end{array}$ & [36] \\
\hline
\end{tabular}

Preliminary simulations indicated a gap between measured and predicted energy use in the renovated building. Lower than expected efficiency of the heat exchanger in the new ventilation system was identified as one potential reason [37]. Hence, the heat recovery efficiency was measured by logging air temperature before and after the heat exchanger, as well as the temperature of supply, exhaust and outdoor air. The temperatures were logged at threeminute intervals and heat recovery efficiency, $\eta$, was calculated with equation 1

$$
\eta=\frac{T_{e}-T_{c e}}{T_{e}-T_{o}} \cdot \frac{q_{\text {supply }}}{q_{\text {exhaust }}}
$$

Where $T_{e}$ is the exhaust air temperature (room temperature), $T_{c e}$ is the cooled exhaust air temperature (after the heat exchanger), $T_{o}$ is the outside air temperature, $q_{\text {supply }}$ is the supply airflow $\mathrm{m}^{3} / \mathrm{s}$ and $q_{\text {exhaust }}$ is the exhaust airflow $\mathrm{m}^{3} / \mathrm{s}$. The pressure difference over the fan was accessed through the unit's monitoring system and the fan chart was used for conversion to air flow. The airflow was balanced during the temperature measurements.

\subsection{Building Energy Simulation and model validation}

The inherent complexity of models, simplifications and parameter combinations makes it impossible for any method to fully validate a model [24,38] or for any model to be a perfect representation of reality [17]. Yet, accurate prediction of the simulated system is the main purpose of any simulation tool, and validation of the results is therefore essential to verify accuracy [17,38-40]. Coakley et al. [39] highlight that accuracy in predicting energy use is usually the only criterion for BES model validation, and that accuracy of the input data or the simulated environment is seldom assessed.

Three basic approaches can be used for validation of BES models: 1) by comparing it to a given and exact solution, analytical validation; 2) by comparing it to peer models with the same input data, peer model validation; or 3) by comparing it to empirically collected data, empirical validation $[24,38,39,41]$. Empirical validation is often seen as a powerful method for 
validation since the model is compared to measurements [38]. In idealized validation, the physics behind a model is tested by using measurements in an unoccupied test cell [24]. IDA ICE has been validated several times using both peer-model validation and idealized test cell validation methods, for example in [42].

Realistic empirical validation compares model results with measurements from an occupied building [24]. Ryan and Sanquist [24] discuss user impact on BES and conclude in their literature review that significant advancements have been made in improving BES-model accuracy through analytical and idealized validation, but that methods for modelling user behavior and realistic approaches to empirical validation are still lacking. Early approaches to empirical validation were mostly based on small test cells, see for example [38,43]. Although there are many recent studies on small test cells, attempts have also been performed on whole building level. Strachan et al. [44] uses measurements under idealized conditions from two detached houses in Germany and compares it to 21 multiple zone simulations from different users and programs. They conclude that many of the programs showed good agreement with measurements, but that some simulations showed disagreements related to user errors. In another publication from the same studied buildings Strachan et al. [45] show that each zone had different parameter sensitivity and they conclude that uncertainty analysis is essential for high-quality simulations. De Wilde [17] also concludes that differences between predictions and measurement are often highly specific to the studied building, making it hard to generalize. There are few attempts at empirical validation of occupied buildings, especially for renovated buildings. Liu et al. [12] study a renovated building in Sweden and compare measurement in one renovated building and another similar unrenovated building against predictions made in IDA ICE to study the effects from renovation on indoor environment. Liu et al. use measured electricity use for the entire building to create domestic electricity schedules for reference apartments, and achieve good agreement between measured and predicted room air temperature and heat demand. Molin et al. [46] and Rohdin et al. [47] use detailed measurements of electricity use on appliance level to validate their BES model against measured indoor temperature in a passive house, also with good agreement.

BES models include two sets of parameters and input data, one relating to the construction of the buildings (materials, architectural layout, HVAC design) and one relating to the occupancy (usage of the building and behavior) [24]. Whereas data on construction is often known or relatively easy to estimate, occupancy and user behavior represent one of the larger uncertainties in building energy use and BES.

BES models are often compared to measured data, and although this is important to ensure that results are close to reality, one should be careful in assuring that individual model parameters are correct [48]. Some authors refer to the concept of model validation [19,24,43] and argue that sensitivity analysis should be performed to understand model uncertainties [48]. A model variation from measured data of less than $\pm 10 \%$ is desirable for models with a time step of one hour [49]. 


\subsubsection{Model description and input data}

The two reference apartments were modelled with each room as an individual zone and all other apartments were modelled as one zone. Indoor temperature set point was determined using the measured indoor temperature in the reference apartments, see Table 4. Construction blueprints and ventilation certificates were used as input data for construction and air flow rates. Leakage determined by the blower door pressurization test was used for infiltration rates in the model (Table 4).

Table 4. Building envelope air leakage and temperature set points for zone and building level simulations.

\begin{tabular}{lcc}
\hline Other information & Before renovation & After renovation \\
\hline Air tightness at 50 Pascal & $0.35 \mathrm{l} /\left(\mathrm{s} \cdot \mathrm{m}^{2}\right)$ & $0.49 \mathrm{l} /\left(\mathrm{s} \cdot \mathrm{m}^{2}\right)$ \\
Indoor air temperature set point & $19.5-19.8^{\circ} \mathrm{C}$ & $21-21.2^{\circ} \mathrm{C}$ \\
\hline
\end{tabular}

Occupancy and appliance schedules were different for room and building level validation simulations. Occupancy and electricity use schedules with a one-hour time resolution were created from measured electricity use and $\mathrm{CO}_{2}$ concentration in the reference apartments (room level validation). Electricity use and occupancy were assumed to be equally distributed in the apartments, since more detailed user patterns are unknown. A climate file was created from measured climatic data. Simplified schedules for internal gains and occupancy were constructed based on findings from the Swedish Sveby program [50], and used for whole year simulations and building level validation, see Table 5. Figure 3 shows the electricity use schedule for apartments in the building. The chosen schedules represent a highly simplified use of the building, and do not show the high diversity between families, time of use patterns, electricity use and thermal loads previously indicated in studies of end-user behavior and activities [51]. Climatic data from the Swedish hydrological and meteorological institute were used to create climate files for building level validation.

Table 5. Assumed use of building for simulation and estimation of yearly heat demand.

\begin{tabular}{|c|c|}
\hline & Assumed usage or input data \\
\hline Electricity use & $\begin{array}{l}30 \mathrm{kWh} / \mathrm{m}^{2} \cdot \text { year, equally distributed over } \\
\text { the year }\end{array}$ \\
\hline Percentage of useful heat gains from electricity use & $70 \% *$ \\
\hline Occupancy & $\begin{array}{l}36 \text { occupants }{ }^{*} \text { in total (normal activity, } 100 \\
\text { W/person), away for work weekdays } \\
\text { between } 8 \text { a.m. to } 5 \text { p.m., otherwise home }\end{array}$ \\
\hline Percentage of useful heat gains from occupants & $100 \%$ \\
\hline Airing ${ }^{* *}$ & $21 /$ s per apartment ${ }^{*}$ \\
\hline Domestic hot water ${ }^{* * *}$ & $25 \mathrm{kWh} / \mathrm{m}^{2^{*}}$ \\
\hline
\end{tabular}

* Based on findings and standard values from the Sveby program

** Modelled as constant additional infiltration

*** Used for comparison purposes in section 3.1. Not included in simulation. 


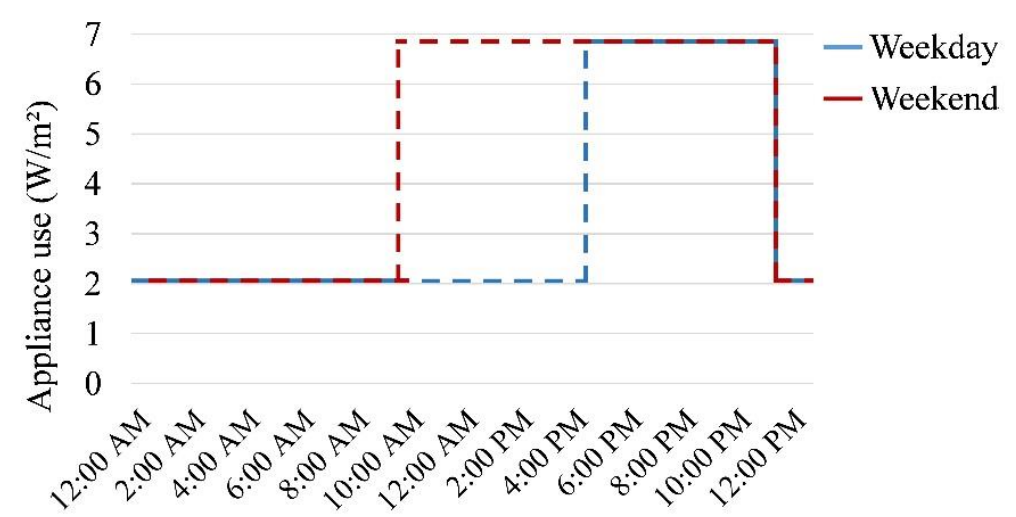

Figure 3. Electricity use schedule for whole year simulations.

\subsubsection{Room level validation}

The measured air temperatures from the two reference apartments were used to validate the model with regard to its ability to predict room temperature, hereafter referred to as room level validation. The apartments are located in different parts of the building and hence will have different heat losses. The reference zones in the model have the same conditions as in reality, and hence the position of the reference apartment in the building will not have a significant impact on the ability to predict temperature, since field measurements have been performed under the same conditions. The simulation was performed on the entire building, not for a single apartment, which means that conditions in neighboring zones are as realistic as possible.

Output data was simulated with a parametric simulation with twelve calculation phases starting two weeks before the room level validation period and ending two weeks after. An output time step of five minutes was used to match the time step of the measured data. Simulated temperature distribution was plotted against measured temperature and the variance was calculated.

The variance, $\sigma^{2}$, between measured and modelled temperature was calculated using equation 2

$$
\sigma^{2}=\frac{\sum\left(X_{\text {measured }}-X_{\text {modelled }}\right)^{2}}{N}
$$

Where $X_{\text {measured }}$ is the measured indoor air temperature at every five-minute interval, $X_{\text {modelled }}$ is the modelled temperature at the same time, and $N$ is the number of measurements during the validation period. The standard deviation, $\sigma$, is calculated as the square root of the variance.

\subsubsection{Building level validation}

When the model's ability to predict the simulated environment was assured in the room level validation, the same model was used for building level validation. This was done by comparing the modelled monthly heat demand from a whole year energy simulation against the measured monthly district heating use from 2013 (unrenovated) and 2015 (renovated). 


\subsection{Parametric study}

To study the model sensitivity to input data and energy-saving measures, the effects on heat demand from different user behavior, levels of insulation and heat recovery, and solar heat gain factor of windows were studied. All simulations were performed with the same basic construction as the model used in the building level validation. Only one parameter was changed for each simulation.

Three aspects of user behavior were analyzed: airing, occupancy and appliance use. These were varied by half (low) and double (high) of the standardized values from the Sveby program, as well as no airing, occupancy or appliance use, see Table 6. Climatic data from 2015 was used. Heat demand per square meter of heated area was noted for each simulation.

Table 6. Variation of user behavior in parametric study of user influences.

\begin{tabular}{lllll}
\hline & None & Low & Medium & High \\
\hline Airing & $0 \mathrm{l} / \mathrm{s} \cdot$ apartment & $11 / \mathrm{s} \cdot$ apartment & $21 / \mathrm{s} \cdot$ apartment & $41 / \mathrm{s} \cdot$ apartment \\
Occupancy & 0 occupants & 18 occupants & 36 occupants & 72 occupants \\
Appliance use & $0 \mathrm{kWh} / \mathrm{m}^{2} \cdot$ year & $12.5 \mathrm{kWh} / \mathrm{m}^{2} \cdot$ year & $25 \mathrm{kWh} / \mathrm{m}^{2} \cdot$ year & $50 \mathrm{kWh} / \mathrm{m}^{2} \cdot$ year \\
\hline
\end{tabular}

The impact on energy performance from different levels of improvement of building envelope and different levels of heat recovery in the ventilation system was studied by performing 20 simulations, where building envelope losses varied between 100\%, 75\%, 50\% and $25 \%$ of the original losses, and ventilation heat recovery with $0 \%, 25 \%, 50 \%, 75 \%$ and 99.9\% efficiency was introduced. All other parameters remained unchanged.

Impacts from choice of solar heat gain factor ( $g$-value) of windows was studied using three different $g$-values for windows in the renovated building. Three simulations were performed with windows with a $U$-value of $1.1 \mathrm{~W} /\left(\mathrm{m}^{2} \cdot \mathrm{K}\right)$ and a $g$-value of $0.25,0.43$ and 0.68 , which represents coated low emissivity windows (e.g. Pilkington SunCool Blue 50/27), uncoated low emissivity windows (e.g. Pilkington SunCool 40/70) and clear glass 3-pane windows (reference value from IDA ICE). Indoor temperature, solar gains, supplied heat and hours with higher indoor temperature than $26^{\circ} \mathrm{C}$ were noted for each simulation.

\subsection{Resource and climate impacts}

When considering local and global resource and climate impact from building energy use, the system in which the building is located needs to be considered. Sweden has good conditions for electricity production with low $\mathrm{CO}_{2}$ emissions, mainly water and nuclear power. The Swedish electricity system is however connected to the Nordic and European electricity system and it can therefore be problematic to look at the local emissions within Swedish borders. A Nordic mix is therefore often used for short-term comparison, and the marginal production when looking at long-term effects. Although district heating systems, which are common in Swedish cities, have a defined system boundary for heat supply, one must keep in mind that changes in the heat demand will have effects on electricity production, if the system is connected to a combined heat and power plant. Many renovation measures also have a great impact on heat demand, but might at the same time increase electricity use (for example when 
installing a more complex ventilation system). Energy system effects from renovations are therefore essential to keep in mind. Although this study makes no attempt to fully analyze the dynamic effects on the surrounding energy system, $\mathrm{CO}_{2}$ emissions and primary energy use are considered to highlight the energy system effects and climate impacts from the renovation. These factors include distribution losses, and the numbers for the Nordic electricity mix take net import and export into consideration [52,53]. A summary of related $\mathrm{CO}_{2}$ emissions and primary energy per MWh factors can be seen in Table 7. Swedish electricity is used for all comparisons regarding primary energy use from electricity. Numbers are all collected from [53] unless otherwise indicated.

Table 7. $\mathrm{CO}_{2}$ emissions and primary energy factors for different energy sources.

\begin{tabular}{lll}
\hline Energy source & $\mathbf{k g C O} \mathbf{e q} / \mathbf{M W h}$ & Primary energy factor \\
\hline Swedish electricity mix & $36.8^{\mathrm{a}}$ & 2.1 \\
Nordic electricity mix & $125.5[52]$ & - \\
Nordic marginal electricity & 759 & - \\
Swedish average district heating & $88.6^{\mathrm{b}}$ & $0.79^{\mathrm{c}}$ \\
District heating Linköping & $99^{\mathrm{b}}[54]$ & $0.19^{\mathrm{c}}[55]$ \\
\hline${ }^{\mathrm{a}}$ based on data from 2008 & & \\
${ }^{\mathrm{b}}$ based on data from 2015 & & \\
${ }^{\mathrm{c}}$ based on data from 2014 & &
\end{tabular}

\section{Results and discussion}

\subsection{Field measurements}

The unrenovated building used 101.3 $\mathrm{MWh}_{\text {district heating }}\left(\mathrm{MWh}_{\mathrm{DH}}\right)$ for heating during 2013. Corrected to a normal year climate using the Energy Index from the Swedish Hydrological and Meteorological Institute, this represents $103.3 \mathrm{MWh}_{\mathrm{DH}}$ or $96.3 \mathrm{kWh} / \mathrm{m}^{2}$.year and 121.3 $\mathrm{kWh} / \mathrm{m}^{2}$.year including standardized domestic hot water use. Mean temperature varied between $19.5-19.8^{\circ} \mathrm{C}$ in the reference zones, which is lower than the recommended indoor temperature in Sweden of $21^{\circ} \mathrm{C}$. In 2015 and after the renovation was performed, the building used 49.4 $\mathrm{MWh}_{\mathrm{DH}}$. The year 2015 was a warm one and corrected for normal year climate the usage was $56.7 \mathrm{MWh}_{\mathrm{DH}}$ or $52.9 \mathrm{kWh} / \mathrm{m}^{2} \cdot$ year and $77.9 \mathrm{kWh} / \mathrm{m}^{2} \cdot$ year including domestic hot water. Indoor temperature was on average $21^{\circ} \mathrm{C}$ in the renovated reference apartments.

At a depressurization of $50 \mathrm{~Pa}$ the air leakage in the tested apartment was $119.5 \mathrm{l} / \mathrm{s}$ before the renovation, representing a building envelope permeability $\left(q_{50}\right)$ of $0.35 \mathrm{l} / \mathrm{s} \cdot \mathrm{m}^{2}$. After the renovation all air inlets had been closed and new supply air ducts were installed. The leakage in the renovated apartment was slightly higher than before renovation with a leakage of $166 \mathrm{l} / \mathrm{s}$ and $q_{50}$ of $0.49 \mathrm{l} / \mathrm{s} \cdot \mathrm{m}^{2}$. An infrared camera was used at depressurization to identify spot leakages in the climate envelope, but none were found. The unrenovated apartment was vacant during the measurement, while it was occupied during measurement after the renovation. The apartment has two doors facing the stairwell, but one was blocked with furniture after the renovation and was therefore not sealed, which could be one reason for higher leakage. Retrofit with new ventilation ducts also means that new holes has to be made in the existing construction and insufficient sealing around pipes or ducts could also lead to an increased leakage. Since the 
leaking air is not cold, i.e., not outdoor air, it is not possible to detect these leakages with an infrared camera. It should also be noted that wind conditions varied between the two occasions, $3 \mathrm{~m} / \mathrm{s}$ for unrenovated condition and $8 \mathrm{~m} / \mathrm{s}$ for renovated condition. Windy conditions are not ideal for airtightness measurements and hence a pressurization test at $50 \mathrm{~Pa}$ was also performed in the renovated apartment showing a leakage of $142 \mathrm{l} / \mathrm{s}$ at $50 \mathrm{~Pa}$ and $0.42 \mathrm{l} / \mathrm{s} \cdot \mathrm{m}^{2}$, indicating that wind could have a slight influence on the measurements. Although the leakage had increased after the renovation, the rates are still low compared to other building types, such as wood frame buildings, and buildings of the same type [5].

The average heat recovery efficiency in the ventilation system was $57.4 \%$. Bypass of the heat recovery unit was noted for several days during the measurement, when the smoke extract fan was automatically turned on due to a problem with smoke sensors. The property owners have had that problem on several occasions since the ventilation unit was put into operation. Calculations of heat recovery efficiency were made when the system had normal operation and measurements when the heat recovery unit was bypassed were excluded.

\subsection{Room level validation}

Accurate prediction of the simulated environment is essential for assuring model validity [39]. Figure 4 shows the modelled and measured temperature distribution in the unrenovated reference apartment during summer. Rather negligible variations between prediction and measurements are seen when the model is run with blinds between panes always drawn, indicating that solar shading has been used to reduce indoor temperature. Other adaptive measures, such as airing, have also likely been performed, since prediction with solar blinds is higher than measurements in early August. 

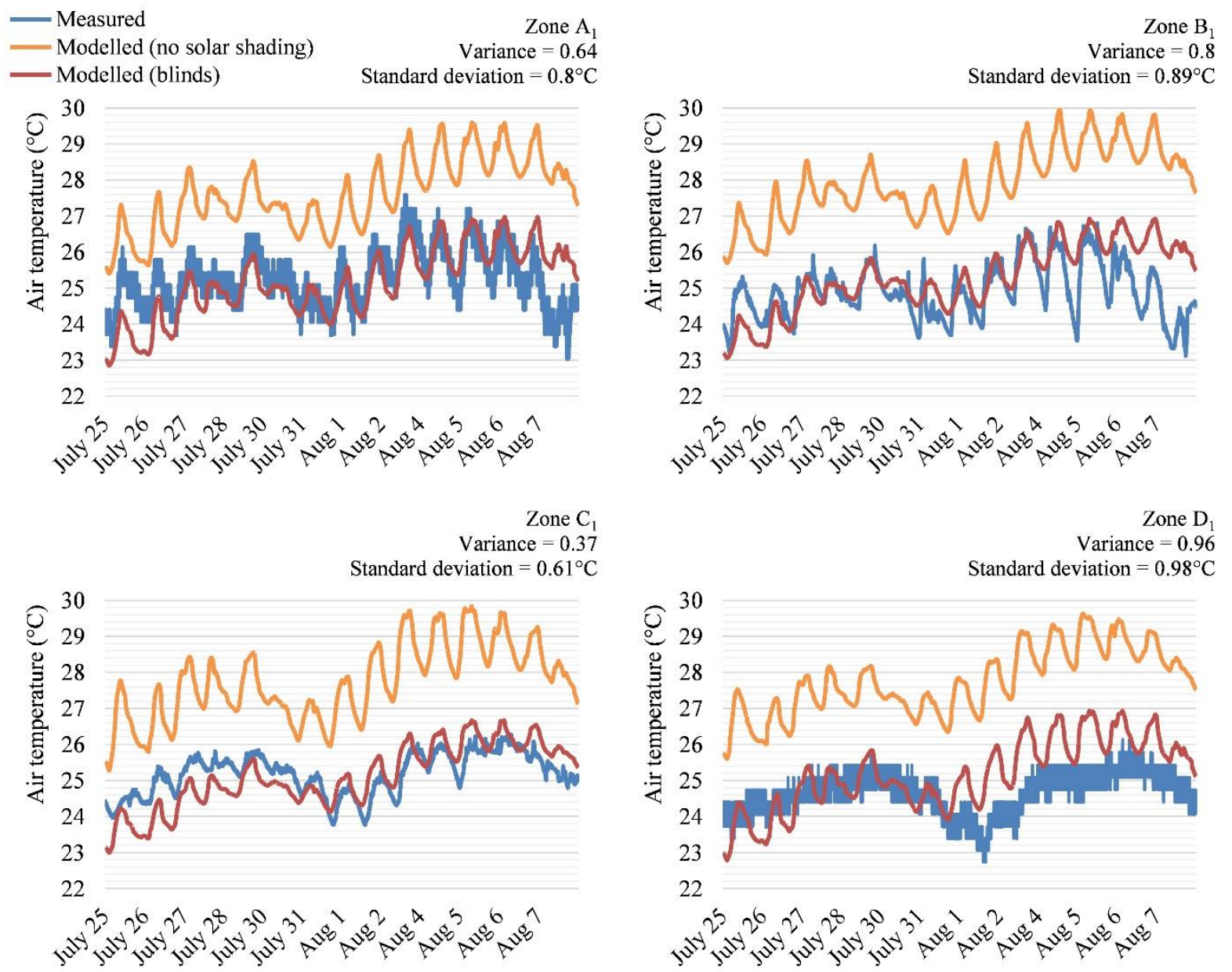

Figure 4. Modelled and measured air temperature in zones between July 25 and August 8, 2013 (unrenovated).

The predicted indoor temperature during the cold validation period has a small standard deviation from measurements in the unrenovated building, see Figure 5. Predicted magnitude of temperature peaks on January 20 and 21 are higher than measurements in zone $\mathrm{B}_{1}-\mathrm{D}_{1}$. Solar radiation was high during these days and the residents have likely used solar shading in these rooms, which lowers the effect from solar radiation on room temperature. Predicted peaks are smaller however in $\mathrm{A}_{1}$, and solar shading has likely not been used in this zone. 


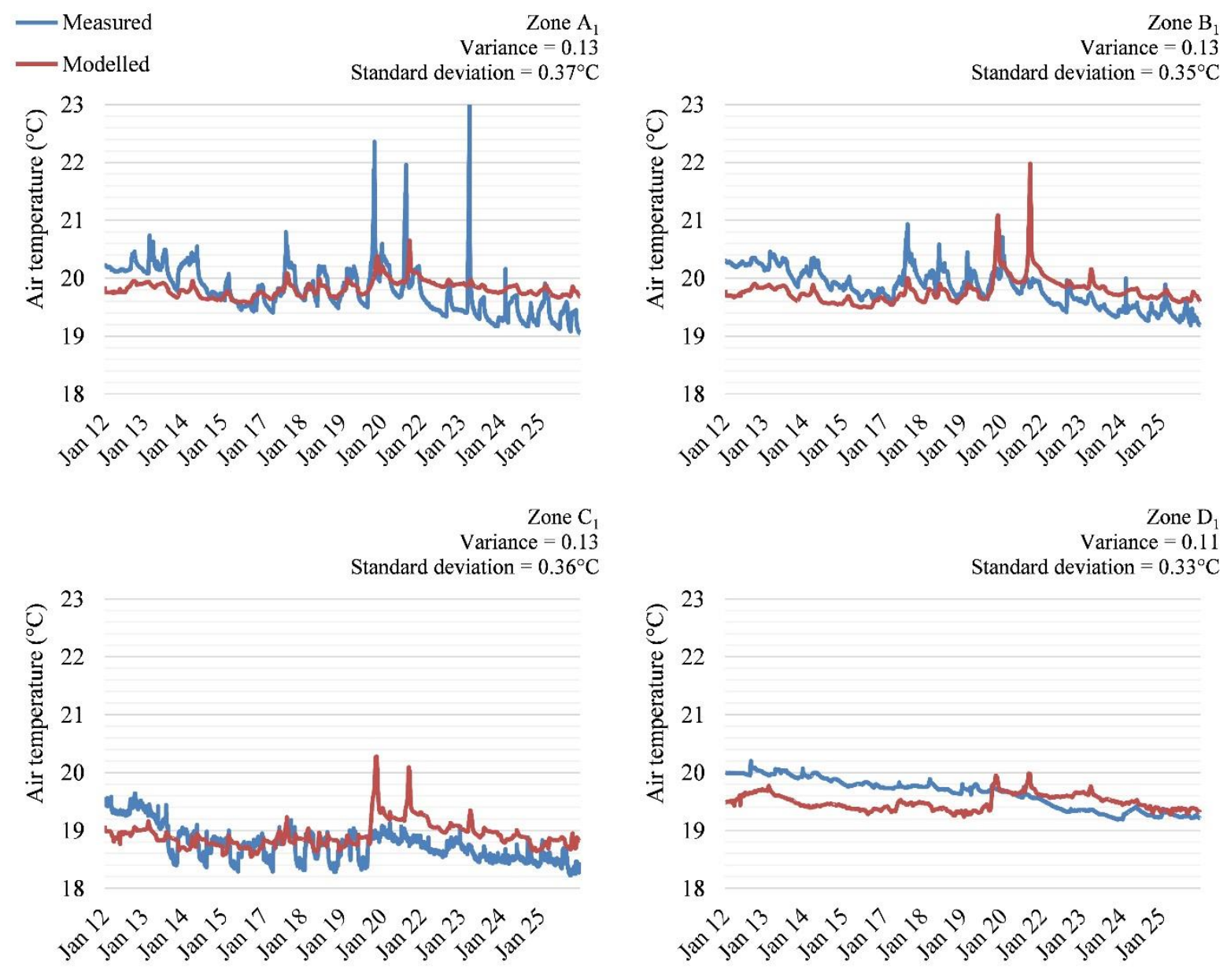

Figure 5. Modelled and measured air temperature in zones between January 12 - 26, 2014 (unrenovated).

The simplified equipment schedule means that internal heat gains from electricityintense appliances that are used during short intervals, such as a desktop computer or cooking appliances, are not always obvious in the predictions. The applied schedules do not seem to catch the activities and equipment use in zone $\mathrm{D}_{1}$ during the days between January 14 to January 20. The model indicates a lowered room temperature, while the measured temperature increases. This could be due to usage of the desktop computer while having the door closed. Overall, variations between prediction and measurements greater than 5\% occur in less than $1 \%$ of the data.

Measured temperatures in the renovated apartment are generally higher and do not fall below $21^{\circ} \mathrm{C}$. Variations between measurements and prediction are generally smaller. A decrease in room air temperature is seen in $\mathrm{C}_{2}$ after March 2. A lowered concentration of $\mathrm{CO}_{2}$ was measured, indicating that the decrease is likely due to airing, and hence the usage schedule applied in the model is likely not consistent with actual use. 


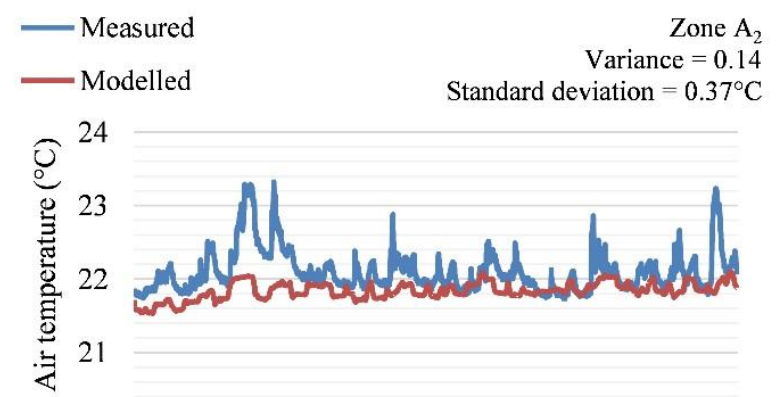

20
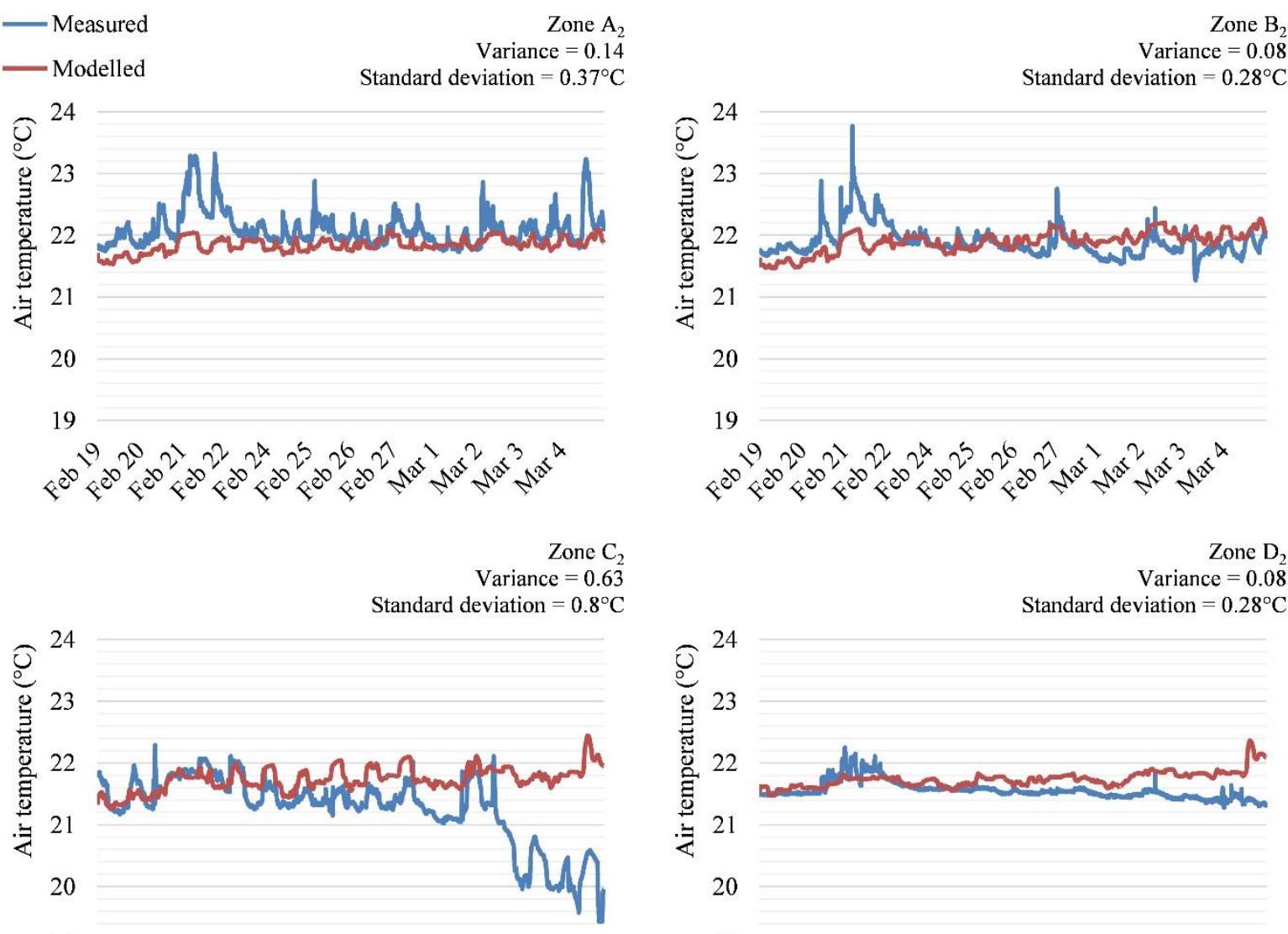

19

20

19

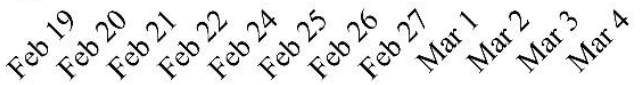

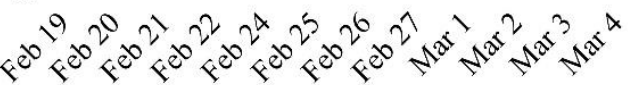
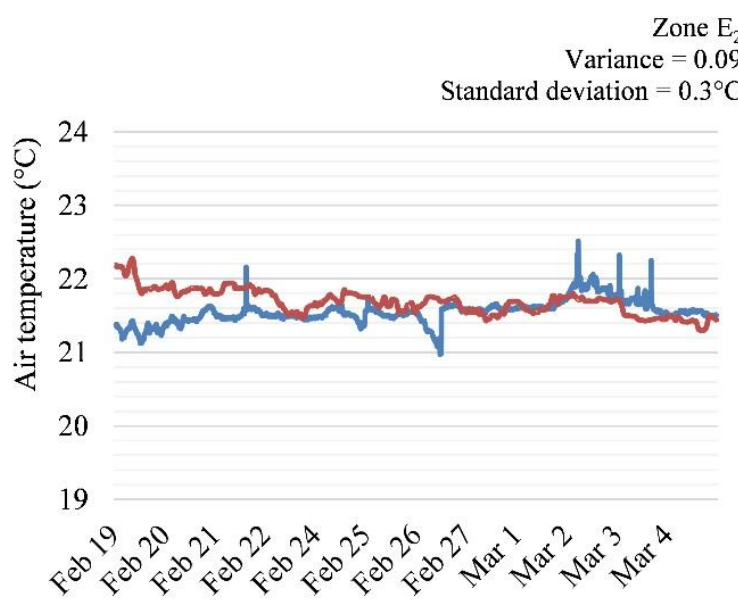

Figure 6. Modelled and measured air temperature in zones between February 19-March 5, 2015 (renovated).

Predicted temperature peaks are not as prominent as actual peaks, indicating that the inertia of the building could be overestimated in the model. Peaks in $\mathrm{A}_{2}$ and $\mathrm{B}_{2}$ occur in the evening and are therefore not related to solar radiation. Instead, the temperature peaks are likely related to appliance use, such as cooking appliances. The appliance schedule with a one-hour time step is not detailed enough to capture these changes. 


\subsection{Building level validation}

The model that has been validated on room level also predicts monthly energy use for heating well. The building had a yearly heat demand of $101.3 \mathrm{MWh}_{\mathrm{DH}}$ and the model predicts a yearly heat demand of $97.5 \mathrm{MWh}$ DH $\left(90.9 \mathrm{kWh} / \mathrm{m}^{2} \cdot\right.$ year $)$, a difference of $3.7 \%$, see Figure 7 .

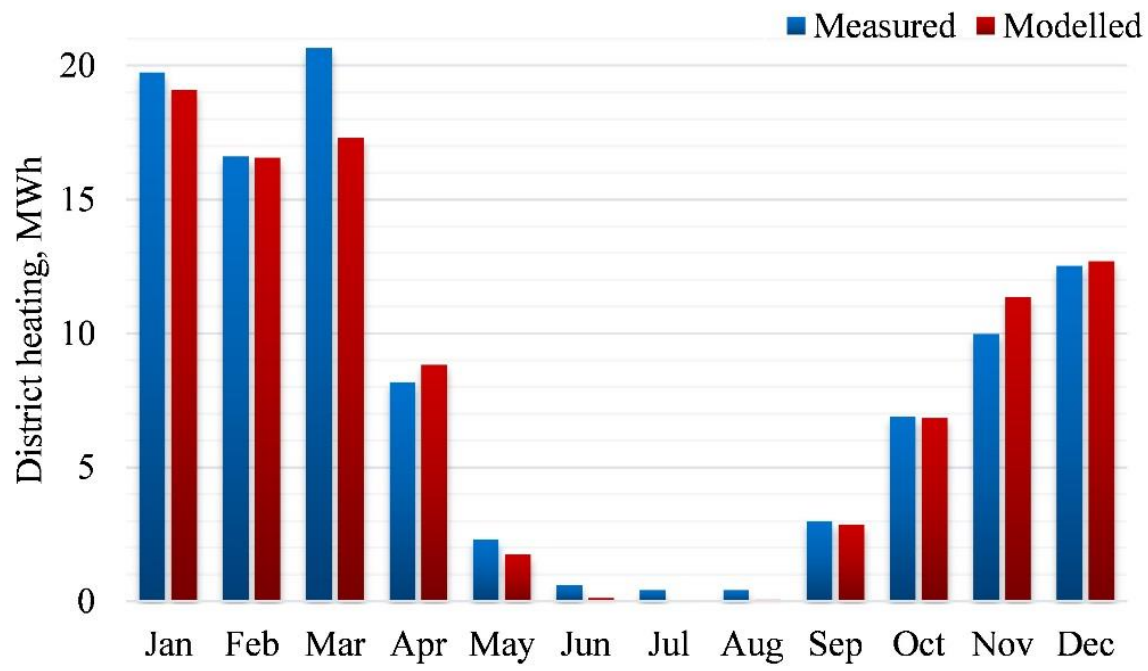

Figure 7. Measured and modelled heat demand during 2013 in the unrenovated building.

Monthly variations between prediction and actual use are small, except for March. The applied schedules for user behavior or occupancy do not seem to entirely match actual behavior in March.

The renovated building had a heat demand of $49.4 \mathrm{MWh}_{\mathrm{DH}}$ in 2015 , and the model predicts a usage of $46.7 \mathrm{MWh}$ DH $\left(43.6 \mathrm{kWh} / \mathrm{m}^{2}\right.$.year) for the same year, see Figure 8 . This is a difference of $5.6 \%$. An uncertainty factor could be the erroneous operation of the smoke extract fan. This could be the case in September and October, where there is a difference of around $25 \%$ between prediction and measurements.

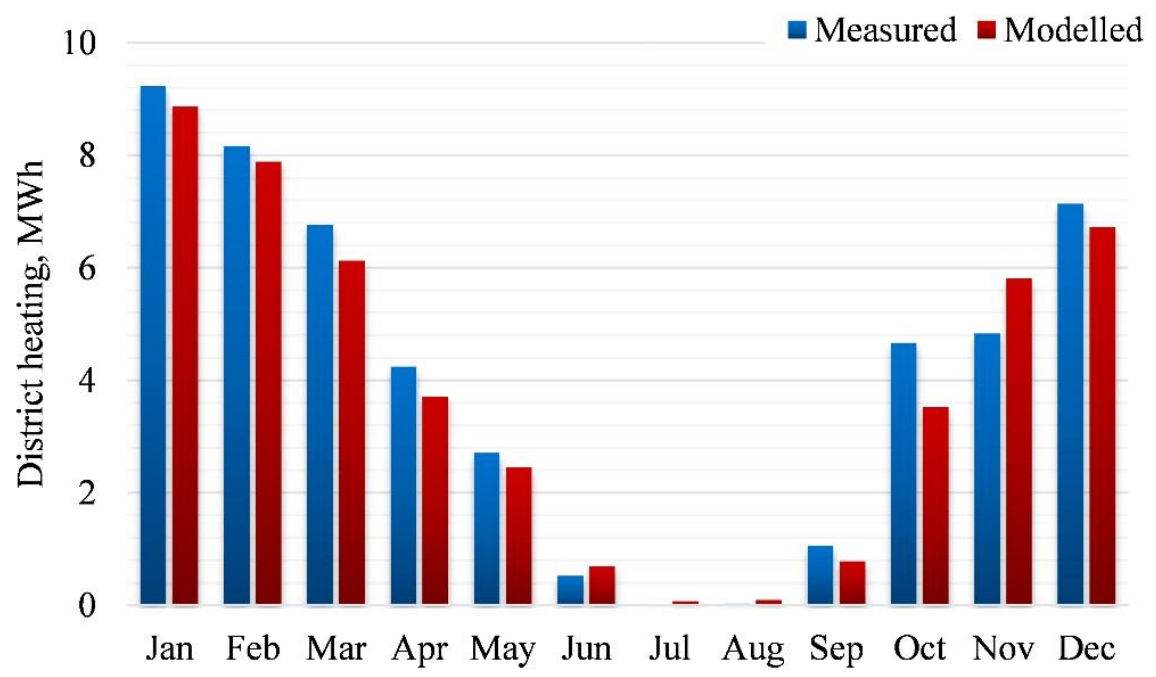

Figure 8. Measured and modelled heat demand during 2015 in the renovated building.

The building had a modelled climate normalized [56] heat demand of $99 \mathrm{MWh}$ before the renovation, which is reduced to 55.4 MWh with the implemented renovation measures. This 
means a reduction of heat demand by $44.0 \%$. An energy use reduction of $34.7 \%$ is achieved when standardized domestic hot water use is included, which is a similar result to contrasting studies presented in Table 1. The building had a lower than normal indoor temperature before the renovation, and with an indoor temperature of $21^{\circ} \mathrm{C}$ the annual heat demand would be 106.7 MWh during a normal year. This gives the selected renovation measures a potential for $48.1 \%$ reduction of heat demand. The heat recovery efficiency in the ventilation system is lower than the property owner had assumed, which also means a smaller reduction than expected.

The building had a balance temperature, for which active heating is required, of $18.3^{\circ} \mathrm{C}$ before the renovation. The implemented renovation measures have reduced this to $16.1^{\circ} \mathrm{C}$. This reduces the number of theoretical heating hours from 8100 hours to 7600 hours during one year. This is also seen in the thermal power from the heating system modelled in IDA ICE, see Figure 9.

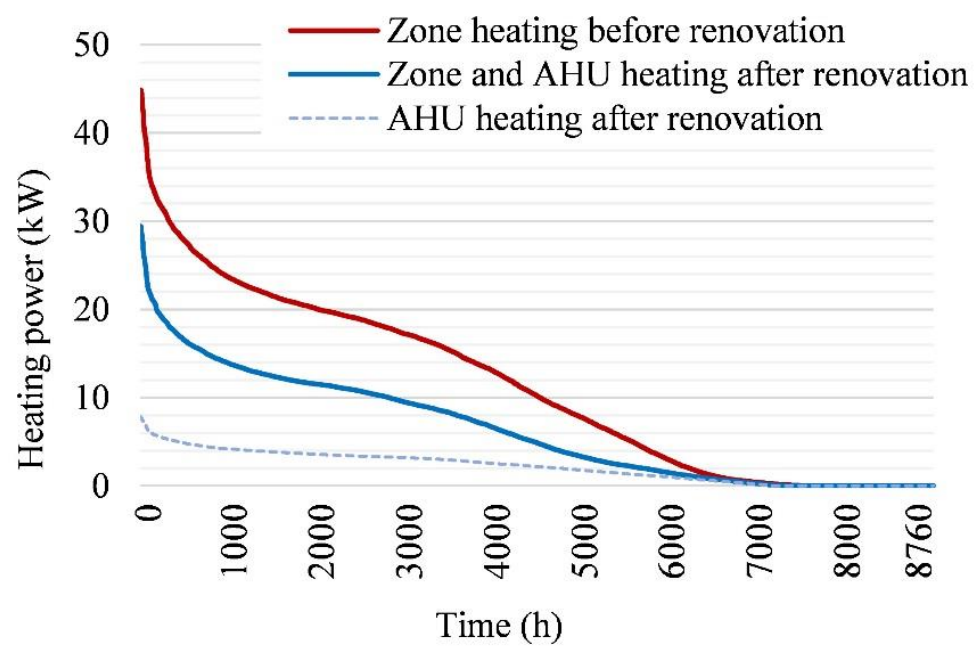

Figure 9. Duration diagram of heating power for space heating. Heating power after renovation consists of combined heating from room units and AHU heating coil. Dotted line shows heat in AHU.

\subsection{Parametric study}

\subsubsection{User behavior}

In any energy simulation it is inevitable that some assumptions have to be made regarding the use of the building or internal gains. These are often based on standard values from engineering assumptions or empirical measurements. This study uses standard values for airing, appliance use and occupancy from a Swedish setting. The sensitivity study of these parameters indicates that appliance use is the most determinant factor, i.e., has the strongest influence on annual heat demand, see Figure 10. Airing, which is often an uncertainty factor and hard for a property owner to control, is the least influencing factor. 


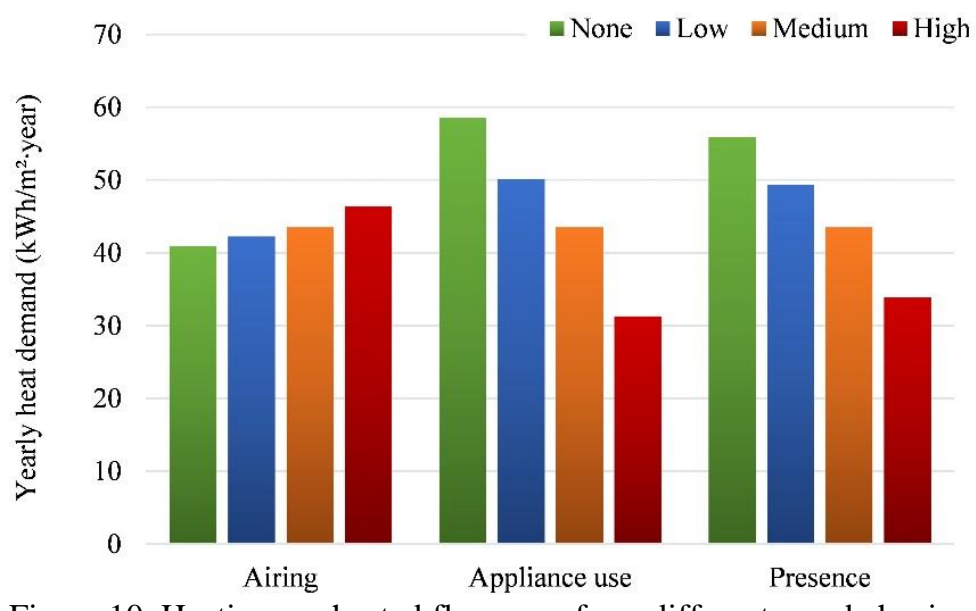

Figure 10. Heating per heated floor area from different user behavior.

\subsubsection{Thermal improvement and heat recovery}

Thermal improvement of the building envelope, i.e., insulation, is a common renovation strategy to reduce energy use of buildings. Recovering thermal energy from return air is another one. Theoretical calculation of $U$-values are generally based on experimental testing in a laboratory environment. Using a calibrated hot box setup, Asdrubali and Baldinelli [57] found small differences between theoretical calculations of inhomogeneous structures and measurements. In their study they found a difference of maximum 3\% for an aluminum framed window. In situ measurements of $U$-values using thermal flux sensors have shown on the other hand that measured $U$-values are generally higher than calculated $U$-values [58]. In their study Asdrubali et al. [58] found that the measured U-value of five out of six studied wall constructions was higher (between 15-43\%) than the theoretical calculations, which could, for example, be due to improper installation of materials. As has been shown in this study, heat recovery systems can also have a lower heat recovery efficiency than expected. Figure 11 and Figure 12 show the achieved results in terms of heat demand and heating power demand from the renovation based on the theoretically calculated transmission losses and measured heat exchanger efficiency. 


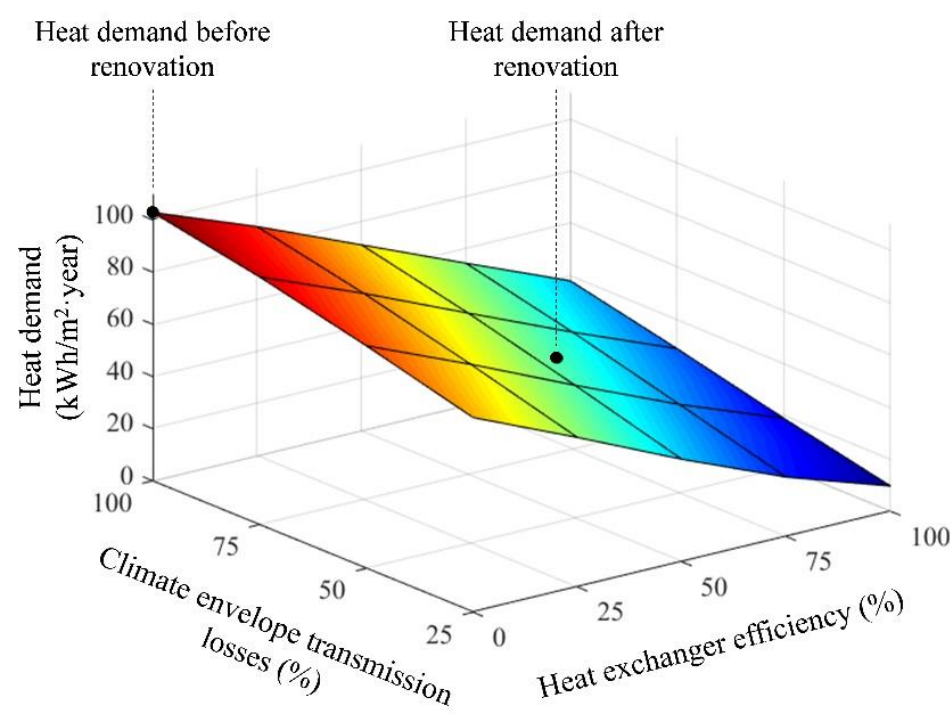

Figure 11. Yearly heat demand per heated floor area from reducing building envelope losses and ventilation losses.

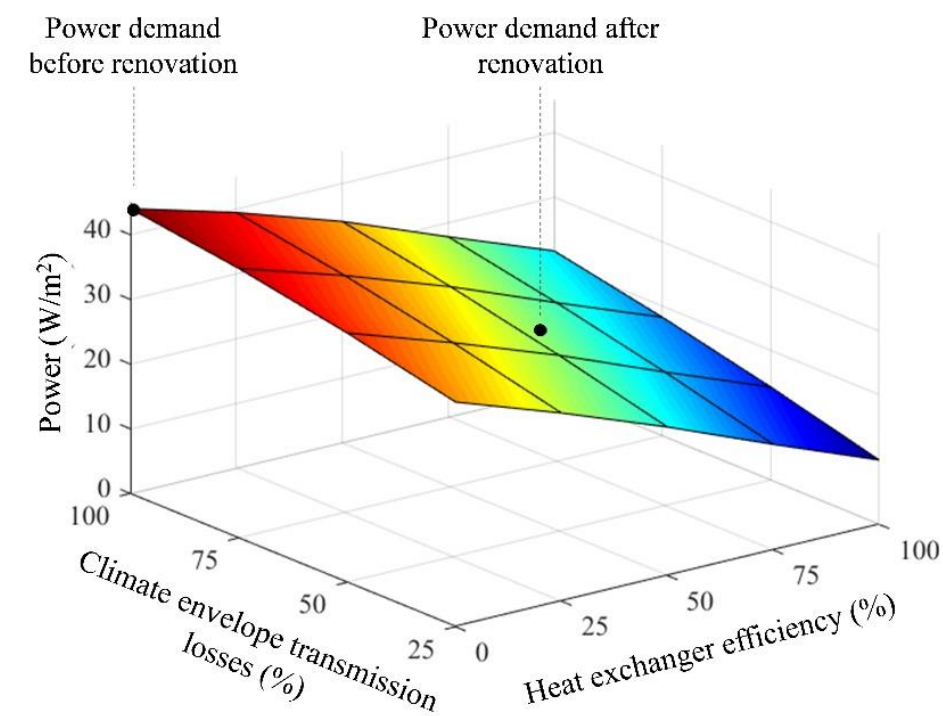

Figure 12. Heating power per heated floor area during a design day from reducing building envelope losses and ventilation losses.

The energy use per heater floor area as a function of envelope transmission losses and heat recovery efficiency can be seen in Figure 11. As long as internal heat gains are useful (i.e., occur during heat deficit), the change in energy use and maximum heating power is linearly correlated with the improvement of the building envelope and the efficiency of the heat recovery system. Figure 12 shows the thermal heating power during a cold design day, when the building is in use, i.e., there are internal heat gains in the building. As in the case with heating, the linear correlation is broken when internal gains represent more than the thermal power required for covering the heat deficit. During a cold design day in cold climate, normal internal gains are unlikely to cover the required thermal power even with very small heat losses. 


\subsubsection{Window solar gain factor}

A low $U$-value of windows is a natural choice in cold climate to reduce heat losses. The solar heat gain factor of the window ( $g$-value) is less frequently considered in residential settings in a cold climate. The windows installed in the building had a $U$-value of $1.1 \mathrm{~W} /\left(\mathrm{m}^{2} \cdot \mathrm{K}\right)$ and a $g$-value of 0.43 (uncoated low emissivity windows), meaning that $43 \%$ of the thermal energy from solar radiation is transmitted through the windows. As mentioned, this yielded a yearly heat demand of $46.7 \mathrm{MWh}_{\mathrm{DH}}$ with climatic data from 2015. The chosen $g$-value gives 116 hours when the indoor temperature is above $26^{\circ} \mathrm{C}$, see Table 8 .

Table 8. Yearly heat demand and hours with indoor temperatures above $26^{\circ} \mathrm{C}$ with climatic data from 2015.

\begin{tabular}{lll}
\hline $\boldsymbol{g}$-value & Annual heat demand & Hours when $\mathbf{T}_{\text {indoor }} \geq \mathbf{2 6}{ }^{\circ} \mathbf{C}$ \\
\hline $\mathbf{0 . 2 5}$ & $48.8 \mathrm{MWh}$ & $20 \mathrm{~h}$ \\
$\mathbf{0 . 4 3}$ & $46.7 \mathrm{MWh}$ & $116 \mathrm{~h}$ \\
$\mathbf{0 . 6 8}$ & $44.1 \mathrm{MWh}$ & $636 \mathrm{~h}$ \\
\hline
\end{tabular}

If a $g$-value of 0.25 (coated low emissivity windows) would have been chosen for a window with the same $U$-value, the number of hours with temperatures higher than $26^{\circ} \mathrm{C}$ would be reduced to 20 hours a year. The heat demand would on the other hand increase to 48.8 $\mathrm{MWh}_{\mathrm{DH}}$. With the $g$-value of a three-pane clear glass window ( $g$-value 0.68 ), the energy use is reduced to $44.1 \mathrm{MWh}_{\mathrm{DH}}$, but also results in 636 hours with temperature above $26^{\circ} \mathrm{C}$. The dynamic effects are seen in Figure 13. Indoor temperatures are higher than desired from around April to October, especially in the two cases with higher $g$-values. The orange area in the figure indicates solar radiation, and this is only useful when there is a heat deficit, i.e., when it can substitute active heating from the heating system (represented in red in the figure). For the lowest $g$-value, a small heat demand can be seen during summer, while the two higher $g$-values mean that close to no active heating is required from June to September. In a geographical setting with cold climate but higher level of solar radiation than Nordic countries, a high $g$ value has an even higher potential for reducing yearly heat demand, but also creates larger problems with high indoor temperatures during summer. A combination with higher $g$-values and external shading could be a suitable option, depending on conditions. 

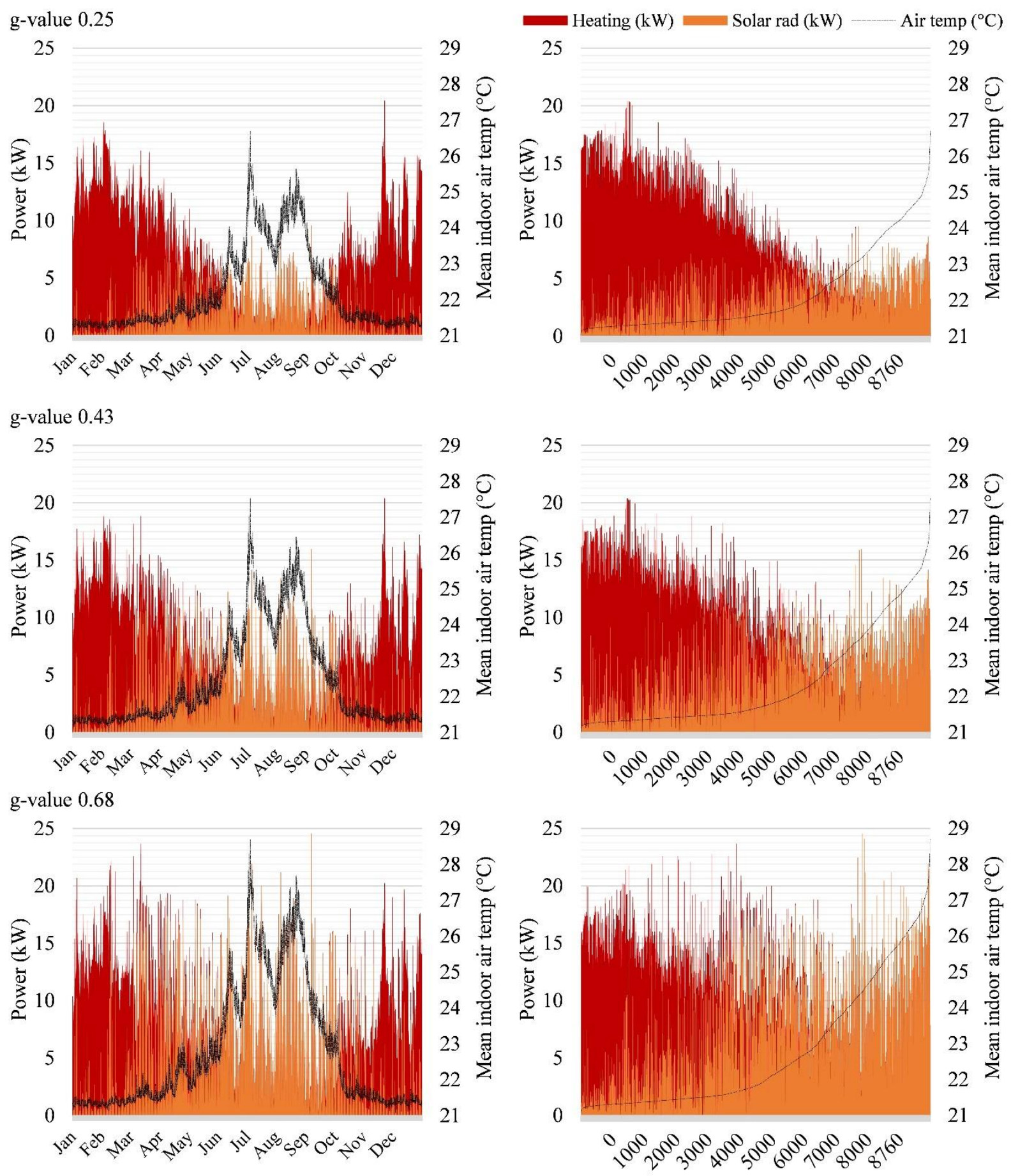

g-value 0.68
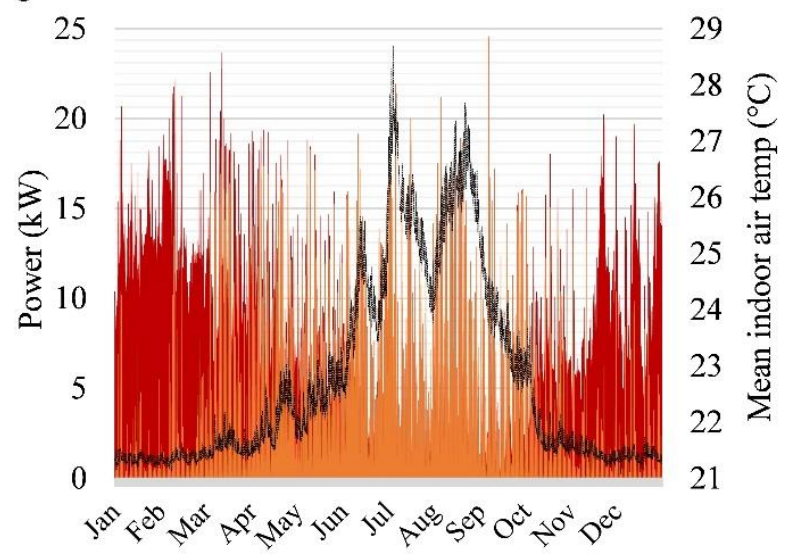

Figure 13. Thermal power from district heating (space heating), gains from solar radiation and indoor temperature for different solar gain factors ( $g$-values) in load diagram (left) and duration diagram (right).

\subsection{Changes in resource and climate impact from renovation}

A more advanced ventilation system, i.e., mechanical supply and exhaust ventilation system with heat recovery, means that more electricity is needed to operate the system. In this renovation electricity use for the newly installed mechanical ventilation systems increased from

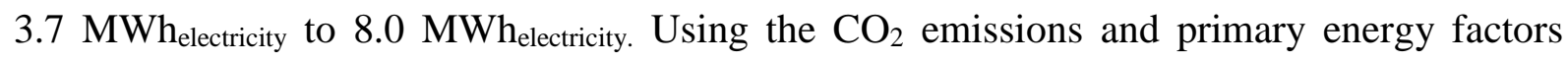
described in Table 7, it is obvious that the choice of system boundary has significant impact on emissions and primary energy use related to implemented solutions. With Nordic marginal 
electricity the emissions related to electricity use constitute around half of the total emissions from building operation and heating (see Figure 14), although the electricity only represents around $15 \%$ of total energy use. With the Swedish average electricity mix and the Nordic mix, $\mathrm{CO}_{2}$ emissions from electricity constitute a smaller part.

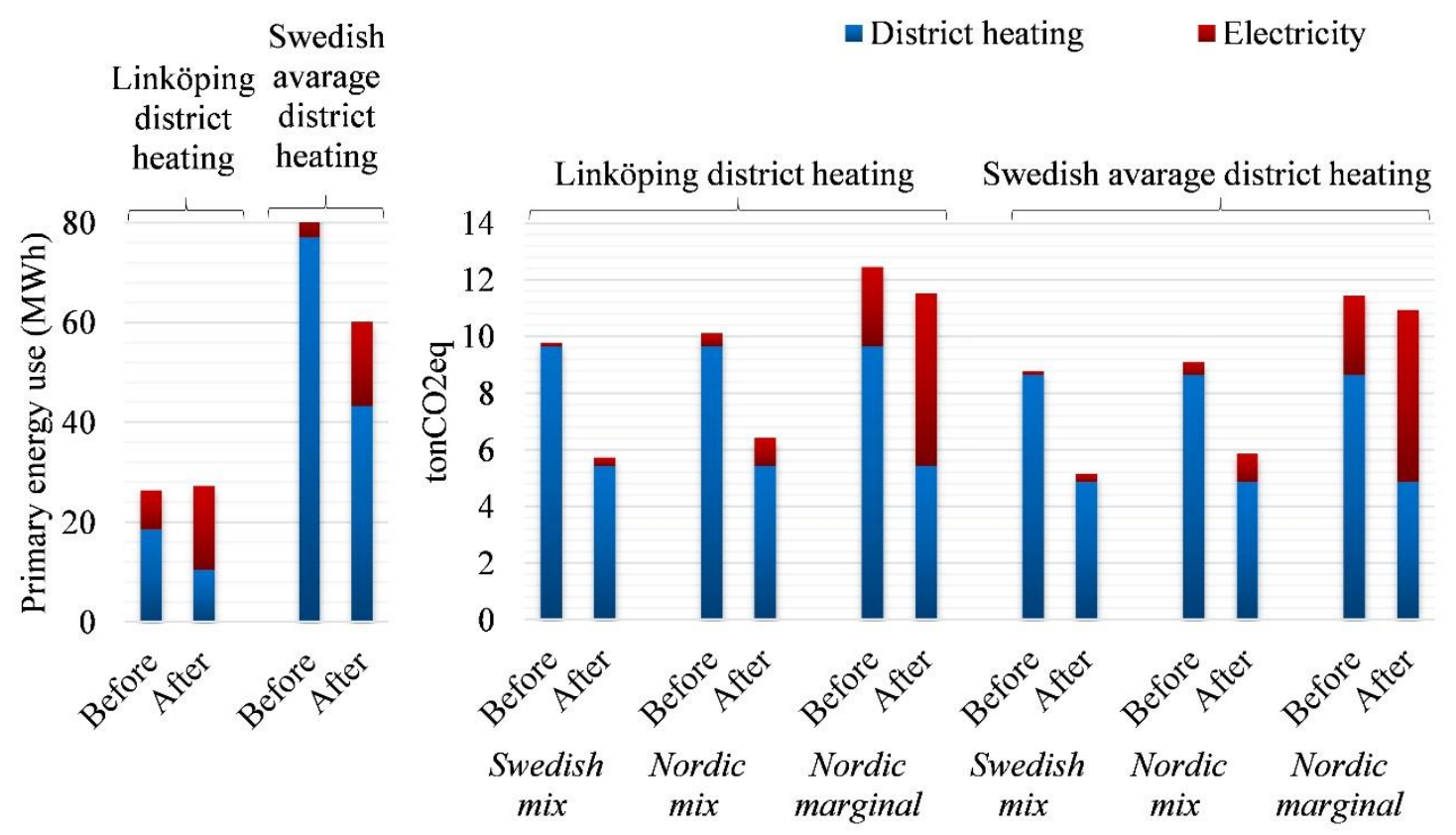

Figure 14. Primary energy use and $\mathrm{CO}_{2}$ emissions from building energy use before and after renovation.

Electricity mix or margin is indicated below staples.

Whereas the district heating system in Linköping has higher $\mathrm{CO}_{2}$ emissions than the Swedish average, primary energy use is significantly lower, see Figure 14. The difference in primary energy use depends mainly on the fact that district heating in Linköping is based on combined heat and power and uses waste as main fuel. The fuel mix and type of plant have a significant impact on the resource impact from building energy use in buildings heated with district heating.

\section{Concluding discussion}

Accurate prediction of energy savings from energy renovation measures is important. This study has shown that the BES model created in IDA ICE is able to predict the indoor thermal environment and energy use with reasonable accuracy. Field measurements that have been performed as part of the study, such as heat exchanger efficiency, room temperature distribution and occupancy during validation periods, have been essential for being able to construct the model as close to realistic operation as possible. The study also shows that selection of user behavior can have a significant effect on estimation of energy-saving potential. Assuming high electricity use for residents could, for example, overestimate reduction in heat demand and result in failure to reach energy-saving goals. Field measurements indicate that the ventilation heat recovery efficiency was significantly lower than what the property owner had assumed. Predicting energy performance in the planning phase of a construction or renovation project is 
complex and evaluation of the building under operation can therefore be a valuable tool for following up on goals and learning for future projects.

The selected renovation strategies reduce energy use by $44.0 \%$, assuming normal operation of the air handling unit and other technical installations. The renovation strategy is similar to those found in contrasting studies and energy saving is also within the same range, see Table 1. As a result of the increased indoor temperature, indoor thermal conditions have been improved and requirements in the Swedish building code are fulfilled. A lower indoor temperature before the renovation means that the energy-saving potential is slightly underestimated and with a normal indoor temperature the reduction would have been $48.1 \%$. Better performance of the ventilation heat exchanger and correct operation would also have improved the outcome of the renovation.

As in any renovation, all choices of measures will have an effect on the entire system and some choices might need extra consideration, such as the tradeoff between decreased energy use due to high solar gain factors of windows, and higher indoor temperatures during summer as a result. Major renovation of buildings will have long-term effects on the energy systems to which they are connected. Buildings in a district heating network based on combined heat and power are in essence a cooling system for the plant and allow for more electricity to be produced. Changes in heat demand in the housing stock will therefore affect the operation of the heat and power plant, and in the end affect the amount of electricity that can be sold to the grid. If the system boundary is placed around the building, the implemented renovation measures will be reasonable, reduce operational cost and an increased electricity use for ventilation will not be particularly problematic. If the system boundaries are widened to include, for example, marginal electricity use, an increase in electricity use means a significant increase in climate impact and primary energy use. Other system boundaries, such as embodied energy in materials and construction, will also significantly affect the resource efficiency of the renovation. Renovation of buildings is therefore complex and specific to geographical context and surrounding energy system, but an important aspect in reducing energy use in the residential building sectors.

\section{Acknowledgements}

This study has been financed by the Swedish Research Council Formas. The authors gratefully acknowledge Mr. Jakob Rosenqvist at the Division of Energy Systems, Linköping University, for help with the field measurements, and the housing company Stångåstaden for information about and access to the studied building.

\section{References}

[1] D. Ürge-Vorsatz, N. Eyre, P. Graham, D. Harvey, E. Hertwich, Y. Jiang, et al., Chapter 10 Energy End-Use: Building, Glob. Energy Assess. - Towar. a Sustain. Futur. (2012) 649-760.

[2] L. Gynther, B. Lapillonne, K. Pollier, Energy Efficiency Trends and Policies in the Household and Tertiary Sectors - An Analysis Based on the ODYSSEE and MURE Databases, (2015).

[3] S. Lechtenböhmer, A. Schüring, The potential for large-scale savings from insulating residential buildings in the EU, Energy Effic. 4 (2011) 257-270. doi:10.1007/s12053-010-9090-6.

[4] M. Morelli, L. Rønby, S.E. Mikkelsen, M.G. Minzari, T. Kildemoes, H.M. Tommerup, Energy 
retrofitting of a typical old Danish multi-family building to a "nearly-zero" energy building based on experiences from a test apartment, Energy Build. 54 (2012) 395-406. doi:10.1016/j.enbuild.2012.07.046.

[5] L. Liu, B. Moshfegh, J. Akander, M. Cehlin, Comprehensive investigation on energy retrofits in eleven multi-family buildings in Sweden, Energy Build. 84 (2014) 704-715. doi:10.1016/j.enbuild.2014.08.044.

[6] K. Difs, M. Bennstam, L. Trygg, L. Nordenstam, Energy conservation measures in buildings heated by district heating - A local energy system perspective, Energy. 35 (2010) 3194-3203. doi:10.1016/j.energy.2010.04.001.

[7] European Parliament, Directive 2010/31/EU of the European Parliament and of the Council - on the energy performance of buildings, (2010).

[8] Swedish National Board of Housing Building and Planning, Bättre koll på underhåll, Boverket, Karlskrona, 2003.

[9] Swedish National Board of Housing Building and Planning, Underlag till den andra nationella strategin för energieffektiviserande renovering, Boverket, 2016. http://www.boverket.se/globalassets/publikationer/dokument/2016/forslag-pa-uppdateradstrategi-for-energieffektiv-renovering_slutversion.pdf.

[10] The Swedish Governement, The Budget Bill 2017. Prop. 2016/17:1, The Swedish Ministry of Finance, 2016.

[11] A. Andersson, D. Larsson, Renovering av flerfamiljsbostäder inom miljonprogrammet ur ett energi- och lönsamhetsperspektiv, Thesis E2013:09, Division of Building Services Engineering, Department of Energy and Environment, Chalmser University of Technology, 2013.

[12] L. Liu, P. Rohdin, B. Moshfegh, Evaluating indoor environment of a retrofitted multi-family building with improved energy performance in Sweden, Energy Build. 102 (2015) 32-44. doi:10.1016/j.enbuild.2015.05.021.

[13] O. Mørck, M. Almeida, M. Ferreira, N. Brito, K.E. Thomsen, I. Østergaard, Shining examples analysed within the EBC Annex 56 project, Energy Build. 127 (2016) 991-998. doi:10.1016/j.enbuild.2016.05.091.

[14] IEA, Annex 56 Cost-Effective Energy \& CO2 Emissions Optimization in Building Renovation - Case studies, (2017). http://www.iea-annex56.org/index.aspx?MenuID=4.

[15] K.E. Thomsen, J. Rose, O. Mørck, S.Ø. Jensen, I. Østergaard, H.N. Knudsen, et al., Energy consumption and indoor climate in a residential building before and after comprehensive energy $\begin{array}{lllll}\text { retrofitting, } & \text { Energy } & \text { Build. } & 123 & \text { (2016) }\end{array}$ doi:http://dx.doi.org/10.1016/j.enbuild.2016.04.049.

[16] K. Kuusk, T. Kalamees, S. Link, S. Ilomets, A. Mikola, Case-study analysis of concrete largepanel apartment building at pre- and post low-budget energy-renovation, J. Civ. Eng. Manag. 23 (2017) 67-75. doi:10.3846/13923730.2014.975741.

[17] P. De Wilde, The gap between predicted and measured energy performance of buildings: A framework for investigation, Autom. Constr. 41 (2014) 40-49. doi:10.1016/j.autcon.2014.02.009.

[18] I. Danielski, Large variations in specific final energy use in Swedish apartment buildings: Causes and solutions, Energy Build. 49 (2012) 276-285. doi:10.1016/j.enbuild.2012.02.015.

[19] N. Fumo, A review on the basics of building energy estimation, Renew. Sustain. Energy Rev. 31 (2014) 53-60. doi:10.1016/j.rser.2013.11.040.

[20] M. Royapoor, T. Roskilly, Building model calibration using energy and environmental data, Energy Build. 94 (2015) 109-120. doi:10.1016/j.enbuild.2015.02.050.

[21] U.I. Dar, L. Georges, I. Sartori, V. Novakovic, Influence of occupant's behavior on heating needs and energy system performance: A case of well-insulated detached houses in cold climates, Build. Simul. 8 (2015) 499-513. doi:10.1007/s12273-015-0230-y.

[22] M. Sunikka-Blank, R. Galvin, Introducing the prebound effect: the gap between performance and actual energy consumption, Build. Res. Inf. 40 (2012) 260-273. doi:10.1080/09613218.2012.690952.

[23] P. Hoes, J.L.M. Hensen, M.G.L.C. Loomans, B. de Vries, D. Bourgeois, User behavior in whole building simulation, Energy Build. 41 (2009) 295-302. doi:10.1016/j.enbuild.2008.09.008.

[24] E.M. Ryan, T.F. Sanquist, Validation of building energy modeling tools under idealized and 
realistic conditions, Energy Build. 47 (2012) 375-382. doi:10.1016/j.enbuild.2011.12.020.

[25] D. Calì, T. Osterhage, R. Streblow, D. Müller, Energy performance gap in refurbished German dwellings: Lesson learned from a field test, Energy Build. 127 (2016) 1146-1158. doi:10.1016/j.enbuild.2016.05.020.

[26] P. Sahlin, L. Eriksson, P. Grozman, H. Johnsson, A. Shapovalov, M. Vuolle, Whole-building simulation with symbolic DAE equations and general purpose solvers, Build. Environ. 39 (2004) 949-958. doi:10.1016/j.buildenv.2004.01.019.

[27] A.M. Aikivuori, Critical loss of performance - what fails before durability, Proceeding 8th Int. Conf. Durab. Of. Build. Mater. Ottawa, Canada 30 May - 3 June 1999. (1999) 1369-1376.

[28] International Standard ISO 6946:2007, Building components and building elements - Thermal resistance and thermal transmittance - Calculation method, (n.d.).

[29] International Standard ISO 13370:2007, Thermal performance of buildings - Heat transfer via the ground - Calculation methods, (n.d.).

[30] Retrotech, Model 1000 Blower Door, (2012). available: http://retrotec.com/support/manualsguides/blower-door-1000-dm-2-spec-sheet.

[31] Retrotech, 6101 Hi-Power Blower Door, (2016). available: http://retrotec.com/products/6101-hipower.

[32] Retrotech, DM-2 Digital Gauge, (2016). available: http://retrotec.com/products/dm-2-digitalgauge.

[33] Gemini Data Loggers, Tinytag Plus 2 Data Loggers, (2016). available: http://www.geminidataloggers.com/data-loggers/tinytag-plus-2.

[34] Gemini Data Loggers, Tinytag CO2 Data Loggers, (2016). available: http://www.geminidataloggers.com/data-loggers/tinytag-co2-data-logger.

[35] ELIQ, Your personal energy advisor, ELIQ, (n.d.). available: http://eliq.se/en/.

[36] IROX, User manual IROX PRO-X2 Weater Station, n.d.

[37] L. La Fleur, B. Moshfegh, P. Rohdin, Chapter 40: Energy performance of a renovated multifamily building in Sweden, in: Proc. Mediterr. Green Build. Renew. Energy Forum 2015, Florence, Italy, Springer, United Kingdom (under publication), 2016.

[38] S.O. Jensen, Validation of building energy simulation programs: a methodology, Energy Build. 22 (1995) 133-144. doi:10.1016/0378-7788(94)00910-C.

[39] D. Coakley, P. Raftery, M. Keane, A review of methods to match building energy simulation models to measured data, Renew. Sustain. Energy Rev. 37 (2014) 123-141. doi:10.1016/j.rser.2014.05.007.

[40] P. Rohdin, M. Dalewski, B. Moshfegh, Indoor environment and energy use in historic buildings - Comparing survey results with measurements and simulations, Int. J. Vent. 10 (2012) 371-382.

[41] M.J. Witte, R.H. Henninger, J. Glazer, Testing and validation of a new building energy simulation program, Proceedings of the Seventh International IBPSA Conference. Rio de Janeiro, Brazil, 13-15 August, 2001.

[42] A. Bring, P. Sahlin, M. Vuolle, Models for Building Indoor Climate and Energy Simulation, 1999.

[43] K.J. Lomas, H. Eppel, C.J. Martin, D.P. Bloomfield, Empirical validation of building energy simulation programs, Energy Build. 26 (1997) 253-275. doi:10.1016/S0378-7788(97)00007-8.

[44] P. Strachan, K. Svehla, I. Heusler, M. Kersken, Whole model empirical validation on a full-scale building, J. Build. Perform. Simul. 1493 (2015) 1-20. doi:10.1080/19401493.2015.1064480.

[45] P. Strachan, F. Monari, M. Kersken, I. Heusler, IEA annex 58: Full-scale empirical validation of detailed thermal simulation programs, Energy Procedia. 78 (2015) 3288-3293. doi:10.1016/j.egypro.2015.11.729.

[46] A. Molin, P. Rohdin, B. Moshfegh, Investigation of energy performance of newly built lowenergy buildings in Sweden, Energy Build. 43 (2011) 2822-2831. doi:10.1016/j.enbuild.2011.06.041.

[47] P. Rohdin, A. Molin, B. Moshfegh, Experiences from nine passive houses in Sweden - Indoor thermal environment and energy use, Build. Environ. 71 (2014) 176-185. doi:10.1016/j.buildenv.2013.09.017.

[48] T.A. Reddy, I. Maor, C. Panjapornpon, Calibrating detailed building energy simulation programs with measured data - Part I: General methodology (RP-1051), HVAC R Res. 13 (2007) 221-241. 
http://www.scopus.com/inward/record.url?eid=2-s2.0-34247520494\&partnerID=tZOtx3y1.

[49] T.A. Reddy, Literature review on calibration of building energy simulation programs, ASHRAE Trans. 112 (2006) 226-240.

[50] Sveby, Brukarindata bostäder, (2012). http://www.sveby.org/.

[51] J. Widén, A. Molin, K. Ellegård, Models of domestic occupancy, activities and energy use based on time-use data: deterministic and stochastic approaches with application to various buildingrelated simulations, J. Build. Perform. Simul. 5 (2012) 27-44. doi:10.1080/19401493.2010.532569.

[52] F. Martinsson, J. Gode, J. Arnell, J. Höglund, Emissionsfaktor för nordisk elproduktionsmix, n.d.

[53] J. Gode, F. Martinsson, L. Hagberg, D. Palm, Miljöfaktaboken 2011 Uppskattade emissionsfaktorer för bränslen, el , värme och transporter, (2011).

[54] Tekniska Verken AB, Carbon dioxide values for Linköping 2015, (n.d.). available: https://www.tekniskaverken.se/miljo/miljorapporter-ochstatistik/miljovarden/fjarrvarme/\#Linkoping.

[55] District heating in Sweden, Environmental values for Swedish district heating in 2014, (n.d.). available: http://www.svenskfjarrvarme.se/Statistik--Pris/Miljovardering-av-fjarrvarme/.

[56] ASHRAE, IDA ICE Climate file - Linköping Malmslätt, Sweden, ASHRAE International Weather Files for Energy Calculations 2.0 (IWEC2), 2016.

[57] F. Asdrubali, G. Baldinelli, Thermal transmittance measurements with the hot box method: Calibration, experimental procedures, and uncertainty analyses of three different approaches, Energy Build. 43 (2011) 1618-1626. doi:10.1016/j.enbuild.2011.03.005.

[58] F. Asdrubali, F. D’Alessandro, G. Baldinelli, F. Bianchi, Evaluating in situ thermal transmittance of green buildings masonries: A case study, Case Stud. Constr. Mater. 1 (2014) 53-59. doi:10.1016/j.cscm.2014.04.004. 